Received: October 8, 2015

\title{
The Landing of CMS Missionaries to an Ottoman Dominion: Missionary Education in Egypt (1825-1862)*
}

\author{
Arzu M. Nurdoğan ${ }^{1}$ \\ Marmara University
}

\begin{abstract}
During the period under investigation (1825-1862), Egypt was a dominion of the Ottoman Empire and attracted the attention and interest of all European states that had been displaying their military and commercial superiority for a long time. In the nineteenth century, Egypt was not only destitute of schools, but had also entered a rapid modernization process since the reign of Mehmet Ali Pasha. This had created an extremely favourable environment for missionary activities in Egypt from the beginning of the nineteenth century. From its findings, this research will attempt to put forth that the missionary schools opened by the Church Missionary Society (CMS) in fact reflected the encouragement of Egyptian Rulers to persons who wished to introduce European institutions. In this respect, the activities of the Protestant societies were not only important for improving the political, economic and commercial interests of England in the region, but also for creating an awareness in Egypt that the most important issues for protecting national existence were raising the level of education and providing cultural development.
\end{abstract}

Keywords

The Church Missionary Society $\bullet$ Ottoman Empire $\bullet$ Cairo $\bullet$ Missionary education $\bullet$ Boys' school $\bullet$ Girls' school

* This paper is a revised and expanded version of a paper entitled "The Landing of CMS Missionaries to an Ottoman Dominion: Egypt" presented at ISCHE Conference, Riga University in August 24, 2013.

1 Correspondence to: Arzu M. Nurdoğan (PhD), Department of Elementary Education, Ataturk Faculty of Education, Marmara University, Istanbul Turkey. Email: arzu.nurdogan@marmara.edu.tr

Citation: Nurdoğan, A. M. (2016). The landing of CMS Missionaries to an Ottoman dominion: Missionary education in Egypt (1825-1862). Educational Sciences: Theory \& Practice, 16, 399-438. 
No part of missionary effort appears to commend itself more universally

to approbation than the education of youth,

And in no part of the world may more auspicious consequences be anticipated,

from its due exercise, than in the Levant

(From Mr. Hartley's letter, Miss. Reg., April, 1832, p. 175).

All missionary societies share the common purpose of spreading Christianity or improving its existing standards. Opposition is expected when the objective is conversion; therefore schools and medical services precede the church. Hence the foremost aim of missionary education is to enable conversion. This is only possible if the Scriptures can be understood and preferably read. The central aim of all Protestant missionary education is Bible study. Local circumstances determine whether the pursuit of this policy is immediately possible, and if it is, how it is possible (Latourette, 1946, pp. 21-23). During the period under investigation (1825-1862), Egypt was a dominion of the Ottoman Empire, and attracted the attention and interest of all European states that had been displaying their military and commercial superiority for a long time. In the nineteenth century, Egypt was not only destitute of schools, but had also entered a rapid modernization process since the reign of Mehmet Ali Pasha. For example, the proceedings for sending Muslim students to Europe in order to be instructed in science, trade or arts, or for establishing modern schools with contemporary curricula and materials were incited by the then Pasha of Egypt, Mehmet Ali (1805-1848). He and his son, Ibrahim Pasha (r. 1848), both seemed to be inclined to extend religious liberty to their subjects, as well (Altundağ, 1988; Heyworth-Dunne, 1939). Therefore, an extremely favourable environment was created for missionary activities in Egypt from the beginning of nineteenth century. From its findings, this research will attempt to put forth that the missionary schools opened by the Church Missionary Society (CMS) in fact reflected the encouragement of Egyptian rulers to those who wished to introduce European institutions. Moreover, during the course of the period under investigation, they tried to ameliorate the ignorance around them and inspire the desire for a better education and a fuller life in people.

The main hypothesis of this research is the necessity that the permanent effects of the missionary activities, the results of which are still felt today, should be understood on the basis of a comprehensive analysis of the process by which capitalism transformed into imperialism. For example, it should not be neglected that the activities of the Protestant societies were not only important for improving the political, economic and commercial interests of England in the region, but also for creating an awareness in Egypt that the most important issues for protecting national existence were raising the level of education and providing cultural development. Within this framework, no studies have so far focused on the educational activities of the English missionary societies in Egypt based on the original resources till date, which has resulted in a 
substantial lacuna (Aksu, 2008a; Arı̆̆, 1999; Aydın, 1996; Aykıt, 2008; Buzpınar, 2003; Dalyan, 2012; Danac1oğlu, 1993; Davison, 1987; Deringil, 2002; Dinçer, n.d.; Erdoğan, 2008; Fortna, 2005; Gündüz, 2004; Gündüz \& Aydın, 2002; Haboubi, 2010; Halidi \& Ferruh, 1968; Haydaroğlu, 1993; Keskinkılıç, 2008; Kırşehirlioğlu, 1963; Kocabaşoğlu, 1989; Mutlu, 2005; Oymak, 2012; Özdalga, 2005; Polvan, 1952; Sevinç, 2007; Somel, 2010; Tozlu, 1991; Turan, 2011; Tümer \& Küçük, 1993; Vahapoğlu, 1997). Although Jack Sislian's article titled "Missionary Work in Egypt during the Nineteenth Century" (1967, pp. 175-240) fills an important gap in this field; however, the fact that the author did not include the letters and reports written by the missionaries (which constitute the most important resource for the field) in his study resulted in many faults. Nevertheless, the CMSA resources present valuable opportunities for carrying out original research concerning this issue, and the present study has been carried out in such a framework to seek out original sources.

This article's intention is not to give a detailed account of the work of the CMS in Egypt, but rather to put forth the reasons and results of the educational plans and efforts that resulted from the Society's connection with Egyptian youths during the first period of the Egyptian Mission (1825-1862). In other words, this research investigates the educational development and the form that it took in CMS schools. Therefore, it also attempts to put forth the impacts of respective schools to the political and cultural evolution process that was initiated in Egypt at that time, and the formation and development processes of these institutions and their status in Egypt.

The research encountered the following problems: (i) How and under what sociopolitical conditions did the CMS missionaries first establish schools in Cairo? (ii) What kind of education policy did the missionaries follow and to what extent was it successful? (iii) What were the impacts of missionary schools in Cairo on the modernization process in Egypt? This research aims to ensure a better comprehension of the impacts of the respective institutions on Egypt's education and modernization process by examining all the schools started by the CMS in Egypt when the country was under the rule of the Ottoman Empire and their activities, and by means of answering the above questions and examining the future of the infrastructure that resulted from the experiences gained during that period, in terms of the educational activities of the second Egyptian Mission (Nurdoğan, 2009, pp. 770-787).

A variety of documents, such as missionary letters, proceedings and annual reports, which are considered the most important documents for research on missionary history, were used in this study to interpret the past. At this point, we have to note that methodological problems resulting from the written materials presented the most limiting aspect of the study. This problem results from the fact that the information related to the schools started by the CMS during the period of the first Egyptian 
Mission (1825-62) was written by missionaries who had no formation in this field, instead of by the educationalist missionaries. This resulted in inefficient information on some basic issues, such as the application of the programs, education-teaching techniques, course books, student-teacher techniques and exams. However, the fact that the objectives of the schools and the time allotted for the courses included in the programs and the languages of teaching were explained meticulously, it prepared a beneficial environment for making general assessments. Another important limitation of the research is the fact that the aspects of the missionary schools that were noted in the Egyptian documents, in other words, the response that Egypt put forward, are only presented in Ottoman archive documents (BOA., S..D. Maarif, 221/4; S.D. Maarif, 213/1; Ş.D. Maarif, 212/61; Ş.D. Maarif, 224/1; Ş.D. Maarif, 208/60; S..D. Maarif, 208/42; Ş.D. Maarif, 221/7; MF.MGM., 6/85; MF.MGM., 7/17; MF. MGM., 8/39; MF.MGM., 9/19). ${ }^{2}$ Nevertheless, this aspect of the issue should not be ignored when attempting to comprehensively reveal the perspective of English expansionism in the nineteenth century in the Levant in general terms and in Egypt in particular terms, within the framework of missionary activities and particularly within the axis of the education system. Nevertheless, we believe that this research shall contribute to future studies by Egyptian historians through its use of local resources.

It is certainly fitting that the CMS had far more work among Muslims than in any other society (CMSA: The Church Missionary Atlas. 1857, p. 69 in Hp 26). ${ }^{3}$ That section of humanity answers in a special sense to the phrase "the East" (CMSA: The Church Missionary Quarterly Paper, No. 269, March, 1883, p. 2 in Hp 35), which is part of the Society's full and original title (the Society for Missions in Africa and the East) (Coldwell, n.d., pp. 77-78, 114; Stock, 1914, p. 113). ${ }^{4}$ CMS's idea of establishing a station in Egypt corresponds to the years during which its attention and interest were focused on the Mediterranean, for the first time since its establishment. The first missionary was sent out to the Mediterranean in $1815,{ }^{5}$ the year of the Battle of Waterloo (Dallas, 2001; Church Missionary Intelligence [CMI], Vol. II, No. 9, September, 1851, p. 196), with the objective to enlighten the Eastern Churches, like the Congregationalist [ABCFM] missionaries in Persia (Hewitt, 1971, p. 294). This missionary was the Rev. William Jowett, who visited Egypt to confer with the ecclesiastical authorities of

2 However no information has been recorded in any of them about the activities of CMS in Egypt.

3 In nineteen out of the Society's twenty-five great Mission fields, Islam was encountered as in the mission of Africa, the Near East, India, and Ceylon. This engagement could be parallel to the feeling of sorrow about the depressed and corrupted condition of the Eastern Churches, which had undoubtedly affected the Church Missionary Society under the Muslim sovereignty, as illustrated in many original papers that belonged to the missionaries (Gollock, 1906, p. 34; CMSA: Miss. Reg., May, 1849, p. 245; Missionary Papers, No. XXV, Lady-Day, 1822, p. 3 in Hp 35). Besides the fact that CMS failed to realise its objectives in Germany, Switzerland and Holland, it managed to make an important enterprise as verified by the expression above. See Stock (1899, pp. 221-222).

4 The reason was the CMS' above-mentioned fact that they found it humiliating that Islam, a fanatical, barren religion, should dominate the lands in which Christ had lived and where the Apostles had worked. The Society, therefore, embarked on an important mission, the aim of which was the revival of the Eastern Churches. It was hoped that this mission would have a notable effect upon the Muhammedan and Heathen World (Coldwell, n.d., p. 15).

5 Kenneth Cragg (2000, p. 123) in his article "Being Made Disciples: The Middle East," erroneously wrote this year as 1816. 
the ancient Coptic Church (1822, pp. 111-124). "We are not", said the Committee, "inciting to a fanatical crusade;" Jowett was to visit and to correspond with "the ecclesiastics at the head of the different communions," so that "through the influence of the Patriarchs of Constantinople, Antioch and Alexandria, our systems of education might be communicated, and Bible societies established" (CMSA: The Church Missionary Atlas. 1857, p. 71 in Hp 26; The Church Missionary Gleaner, Vol. I, May 1874, no p.nr.; Jowett, 1822, p. 276). Although the Society's communicated like this, there were those who considered the missionary movement as a new crusade, which gained speed once the Ottoman Empire entered a modernization process. According to this perspective, this "was a period for a new crusade-not a tide of war, but one, the weapons of whose warfare should be mighty through God to the pulling down of strongholds; and whose aim should be to free the Oriental Christians from the yoke of ignorance and sin" (CMSA: CMI, Vol. II, No. 9, September, 1851, p. 201).

Jowett was in Egypt for some months in 1819, ${ }^{7} 1820$ and again in 1823 (1822, p. 89) $)^{8}$ and often interacted with the priests and monks of the Coptic Church, and distributed many Arabic copies of the Scriptures (CMSA: Missionary Papers, No. XXV, Lady-Day, 1822, p. 3 in Hp 35; Coldwell, n.d., p. 39). He believed that, if the CMS established a Station in Cairo (CMSA: 29 August 1834, The Star in the East and Friend of Youth, No. 12, p. 4), there would be considerable advantages under the protection of the British Consul-General (Jowett, 1822, p. 369). ${ }^{9}$ He listed these advantages as follows: (i) The importance of its connection with Abyssinia; (ii) The easy interaction with Upper Egypt via the Nile; (iii) The existence of a large and diverse population - Copts, Bedouin Arabs, Fellahs, Turks, Greeks, Jews, Armenians, Ethiopians and other African tribes - from many parts of Africa; and (iv) The high possibility of adaption by attempting an educational plan for North Africa (Jowett, 1822, p. 369). ${ }^{10}$ The fact that the population of Copts ${ }^{11}$ in Cairo was larger than that of

$6 \quad$ According to the Committee's instructions to Jowett, which are printed in the Appendix to the Society's Sixteenth Report delivered by Edward Bickersteth (Stock, Vol. I, 1899, p. 349), or to Josiah Pratt, a great part of whose work was to comprise inquiries into the religious state of the Oriental Churches. It was thought that they might be roused to self-reformation, and that then, through them, the Gospel might be spread among the Muhammedans (CMSA: The Church Missionary Atlas. 1857, p. 71 in Hp 26; Missionary Papers, No. LI, Michaelmas, 1828, p. 2 in Hp 35; The Church Missionary Quarterly Paper, No. 269, March, 1882, p. 2. in Hp 35; Miss. Reg., September, 1829, pp. 407-408; Stock, Vol. I, pp. 224-225, Vol. IV, p. 119; The Church Missionary Gleaner, Vol. I, May 1874; Church Missionary Intelligence, Vol. II, No. 9, September 1851, pp. 194-195; Proceedings of the CMS for Africa and the East [Proceed.], London: Ellerton and Henderson Printers, 1815-1816, pp. 142-143).

7 Although Sislian stated that first contact between the CMS and Egypt was realized in 1815 by means of Jowett, the correct date must be 1819 (1967, p. 185).

8 The Missionary Papers accidentally wrote that Jowett visited Egypt twice, instead of three times (CMSA: Missionary Papers, No. LI, Michaelmas, 1828, p. 2 in Hp 35).

9 The most ardent supporter of Lieder and others in both Cairo and Alexandria was Mr Gliddon, whose son was Schoolmaster at the Boys' Day School (CMSA: Müller to Coates, July 30, 1832, CM/O73/59; Lieder to Coates, August $21,1826, \mathrm{CM} / \mathrm{O} 48 / 1)$. This respective person was committed to provide any support in relation to the problems faced by the CMS schools in 1840 (CMSA: Miss. Reg., August, 1841, p. 377).

10 Lieder had pointed out some issues among from the qualities that distinguished Cairo from other cities in the Mediterranean (CMSA: Lieder to Coates, January 10, 1832, CM/O48/10; Miss. Reg., September, 1829, p. 411).

11 There were two classes of Copts: Muhammedans and Christians. Out of a population of 4 to 5 million Copts, the descendants and representatives of the original Christian population of Egypt were estimated to be no more than 200.000 (CMSA: Miss. Reg., May, 1832, p. 227). 
Alexandria (CMSA: Dr Richardson's Communications upon Egypt and Syria, January 1, 1819, CME/3/38) had made Cairo a centre for the Egyptian Mission. ${ }^{12}$ Moreover, it was considered to be the most tolerant Muslim region in Egypt with regard to missionary activities, ${ }^{13}$ or in Mr Wolters's words "perfect liberty of conscience has been granted by the Sultan to all his Christian subjects" (CMSA: Miss. Reg., May, 1849, p. 241), which was one of the attractive aspects of Cairo (CMSA: The Church Missionary Gleaner, Vol. XIV, 1864, p. 74; Miss. Reg., May, 1832, p. 229).

Additionally, Jowett had attracted attention to the fact that the system of mutual instruction had become successful in the region, as seen in the Methodist schools, and he stated that the respective system had to be taught to native teachers via seminaries to be started in Cairo, or that some European assistants had to be appointed. According to him, the nature of this system should previously have been submitted for the approbation of the ecclesiastical or civil superiors of the place or country where it was to be introduced, with a full explanation of every part in the local language and in a manner adapted for local use. The main reason for his confidence in mutual instruction was the positive result obtained from the system's previous success in Malta (Jowett, 1822, pp. 307-308).

\section{The Beginning of the Missionary Enterprise in Egypt}

The CMS first incorporated Egypt in 1825 as a part of what was then called the Mediterranean Mission, which had the objective to revive the Eastern Churches, especially the ancient Coptic Church that was under the influence of the American Presbyterian Mission (CMSA: Proceed., 1922-1923, p. 29; Karas, 1986, pp. 211215), and incite them to preach Christianity to the Muhammedans and eventually to win the Muslim world. The direction of the of the missionaries' activities in that period particularly aimed towards the Copts from among the many other Oriental Christians had resulted from the fact that they were not prohibited to read the Holy Scriptures (CMSA: Lieder to Coates, January 10, 1832, CM/O48/10). Notably Jowett, the first missionary sent to the Mediterranean by the Society, Krusé and other missionaries that had served at the Cairo station for years for years emphasized that utmost attention should be paid to the Egypt station as compared to the other places in the Mediterranean. They listed their reasoning as follows: (i) The Scripture and religious tracts could be distributed throughout Egypt without obstacles; (ii) It was permitted to establish schools everywhere, with many places having the best prospect for success (CMSA: Krusé to Coates, June 30, 1836, CM/O45/176). These resulted in the main reason for the direct attempts of the CMS to reach the Eastern Christians,

12 Moreover, the existence of the Wesleyan Missionary Society, which was represented by McPherson in Alexandra, had affected his idea (CMSA, Lieder to Coates, August 21, 1826, CM/O48/1).

13 "There is more toleration in Egypt than in any other part of the Muhammedan Empire and in Egypt the Christian missionary is tolerated" (CMSA: Miss. Reg., May, 1832, p. 231; Lieder to Coates, January 10, 1832, CM/O48/10). 
namely, because they presented a real obstacle to the Muhammedans' evangelization, instead of being effective instruments for converting them to Christianity (Stock, Vol. I, p. 222, Vol. II, p. 144, Vol. III, p. 113). ${ }^{14}$ This made Egypt a crucial field for the CMS. Consequently, by the end of 1825 , when there were no other laborers except a missionary from the Wesleyan Society at Alexandria (CMSA: Miss. Reg., September, 1829, p. 411),${ }^{15}$ five missionaries were sent to Egypt by the CMS. These were Samuel Gobat, ${ }^{16}$ William Krusé, Theodor Müller, John Rudolph Theophilus Lieder, and Christian Kugler (Coldwell, n.d., pp. 39-40; "Register of Missionaries," n.d., p. 21; Stock, Vol. I, p. 350). All five were from the Basle Protestant Seminary in Switzerland (Sundkler \& Steed, 2000, pp. 112-113). Gobat and Kugler later went on to Abyssinia, while the others travelled across Egypt, visited the Coptic schools, ${ }^{17}$ distributed sections of the Bible amongst both Christians and Muslims, and subsequently opened schools in Cairo. The copies of the Scriptures and other works circulated by them were not only in Arabic, the vernacular language in Egypt (CMSA: Lieder to Coates, January 10, 1832, CM/O48/10), but also in Coptic, Turkish, Greek, Hebrew, Syriac, Armenian, Amharic, English, German, Italian and Spanish (CMSA: Lieder to Coates, January 10, 1832, CM/O48/10; Proceed., 1828, p. 61; Proceed., 1845, p. 46; Miss. Reg., 1829, p. 172, Miss. Reg., 1831, p. 144; Miss. Reg., 1832, pp. 131, 234; Miss. Reg., 1834, pp. 402, 408; Miss. Reg., 1839, p. 379; Miss. Reg., 1844, pp. 310, 352; Report on the Past and Future of the Mediterranean Mission, 1875, $\mathrm{CM} / \mathrm{O} 8 / 101)$. The main motive of these missionaries was undeniably their belief in the superiority of their own faith and praxis. ${ }^{18}$ The missionaries maintained a similar view beyond the distribution of the Scriptures and religious tracts and sought to enter into peoples' domestic circles. However, only physicians and priests were allowed to visit them in their own houses, especially concerning the female class. To overcome this difficulty, Lieder dedicated himself to the study of medicine, and succeeded in visiting families by practicing it without asking for payment ${ }^{19}$ (CMSA: Lieder to

14 "Both Eastern and European Christians are themselves a very great hindrance to the conversion of the Muhammedans.... They judge of the Christian religion by the conduct of the Christians around them and comparing themselves with them, they feel themselves superior" (CMSA: Miss. Reg., May, 1832, p. 233). Lieder gives such an example in relation to this: "If a missionary begins in a religious conversation to preach the Gospel to a Muhammedan, he will very often break off the conversation by saying: 'Would you wish to make me so bad a man as your Christians are?' The missionary has therefore now at first to prove that those only are nominal and not true Christians, upon which the Muhammedan sometimes will answer, "Well if they are not true Christians, they bear your name, convert them therefore at first." Lieder completely agreed with these responses and claimed that their primary duty in Egypt was the rehabilitation of the Christians (CMSA: Lieder to Coates, January 10, 1832, CM/O48/10).

15 The starting date of the Egyptian Mission has been recorded as 1826 in the two issues of the Church Missionary Atlas (CMSA: The Church Missionary Atlas. 1857, p. 68; The Church Missionary Atlas. 1859, p. 18).

16 The Bishop of the United Church of England and Ireland in Jerusalem, after 1846 ("Register of Missionaries" n.d., p. 20).

17 Lieder wrote about these schools in his letter to Jowett: "I have seen several schools and found them more wretched than you have described them in first volume of your Christian Researches." (CMSA: Lieder to Jowett, January 17, 1827, CM/O73/5).

18 This claim is verified by the following expressions from one of the Lieder's letters: "It is known that these Eastern Christians have entirely lost the right sense of these most essential doctrines of the true Church of Christ." (CMSA: Lieder to Jowett, January 17, 1827, CM/O73/5; Wilson, 2002, pp. 30-91).

19 Although Lieder did not charge his patients in return for treatment, he brought along a box and asked whether they wanted to put something in it. He used what accumulated in the box for education of the poor students at the school (CMSA: Lieder to Coates, December 9, 1831, CM/O48/9). 
Coates, August 27, 1831, CM/O48/6; Lieder to Jowett, September 9, 1831, CM/ O48/7), and by having religious interactions with them (CMSA: Lieder to Coates, December 9, 1831, CM/O48/9; Müller, Krusé \& Lieder to Brenner, January 11, 1831, $\mathrm{CM} / \mathrm{O} 73 / 52)$. Thus, the people's prejudices against the missionaries were eradicated by Lieder's practice of medicine among them (CMSA: Lieder to Coates, August 27, 1831, CM/O48/6; Lieder to Coates, December 9, 1831, CM/O48/9; Consideration on Mr. Lieder's practising medicine in Egypt for money, July 2, 1831, CM/O39/138; Lieder to Coates, January 10, 1832, CM/O48/10; Miss Reg., 1832, p. 234; Miss. Reg., 1834, p. 312; Miss. Reg., 1838, p. 234; Miss. Reg., 1847, p. 303). ${ }^{20}$

The missionaries had to pursue three different ways in Egypt to obtain the Society's main purpose:

(i) The forming of Christian schools;

(ii) Conversation on the most essential doctrines of the Bible with those whom the missionaries visited in their houses and abroad, or the preaching of the Gospel from house to house;

(iii) The spreading of the Holy Scriptures \& other books throughout the country (CMSA: Lieder to Coates, December 9, 1831, CM/O48/9; Krusé's Observations Relative to the Egyptian Mission, September 13, 1832, CM/O45/27; Morrison, 1936, Foreword).

\section{The Foundation of Boys' Schools}

Educated Christian schoolmasters were essential for the establishment of efficient Christian schools, however, these could be found among the Copts and other tribes (CMSA: Miss. Reg., 1827, pp. 586-587; Holmes, 1967, p. 30) When Krusé spoke to the Coptic Patriarch about starting a school, he gave his consent and promised to send out a priest in search of a good schoolmaster. The missionaries were content until a priest would ask them whether they would give the children food and clothing. When Krusé and Müller expressed surprise, the priest told them that the English missionaries in India were doing this and that it was likewise expected of the missionaries in Egypt. The missionaries refused to comply at first, but changed their minds later (CMSA: Krusé to Jowett, February 4, 1828, CM/O73/12). Moreover, the Society granted salaries to schoolmasters for educating children whose parents were unable to do so before they started their educational work in Cairo (CMSA: Hinde to Jowett, March 4, 1826, CM/O8/10). It took approximately three years before the school was opened, because the Committee's intentions were not well known to its members in Cairo, who were subsequently unsure

20 Hanna Bachari, chief of the Christians in Egypt, was among the patients treated by Mr. Lieder. Lieder revealed that she had an extremely negative attitude towards him in the beginning; however, she later became his biggest supporter who helped him become acquainted with new families (CMSA: Lieder to Coates, August 27, 1831, CM/O48/6). 
whether the allocated budget for the Mission would allow for it or not. However, the complete agreement that was reached between the headquarters and the members in Cairo about this issue (in the beginning of the year 1828), created an opportunity for taking action in relation to this issue. The Society's schools in Cairo opened with the impression that, as products of universal missionary experience, they embodied the generation on the rise, and believed that they ought to be the prime object of the care and labors of settled missions everywhere. One of the their chief designs was to show the people what a school ought to be like in general, by presenting them a model-school (CMSA: Lieder to the Sec.s of the CMS, January 25, 1839, CM/O45/75b).

Subsequently, the mission's educational work was initiated by the opening of a school, the Boys' Day School [BDS], in the Coptic quarter of Osbekieh, which was mostly inhabited by Copts and Syrians of a higher rank (CMSA: Müller to Schlienz, December 1, 1834, CM/O73/74) $)^{21}$ in Cairo in May 1828 (CMSA: Müller, Krusé \& Lieder to Brenner, January 11, 1831, CM/O73/52; Krusé to Coates, June 30, 1836, CM/ O45/176), which was attended by 18 pupils. Although Jack Sislian wrote in his study that the school had been opened under the administration of Dr. Kluge, the president of the school was in fact Krusé. ${ }^{22}$ Kluge was a German Doctor of Philosophy (CMSA: Krusé, Müller, Lieder \& Kluge to Jowett, no date, CM/O73/23), who, although not a CMS missionary (CMSA: Krusé, Leider \& Müller to Jowett, February 4, 1828, CM/O73/12) but a friend of the Cairo missionaries (CMSA: Isenberg to Schlienz, July 1, 1834, CM/ O73/71), taught Arithmetic and writing courses at this school (CMSA: Proceed., 1828, pp. 63-64; Lieder to Schlienz, June 20, 1828, CM/O73/24; Krusé to Schlienz, April $12,1838, \mathrm{CM} / \mathrm{O} 73 / 21)$. Kluge's lessons continued until the end of the year 1828, when he had to leave the service of the Society by order of the CMS Committee in 1829 (CMSA: Lieder to Schlienz, February 21, 1829, CM/O73/29; Gobat to Kugler, April 17, 1828, CM/O45/2; Journal of Mr. Krusé, April 18, 1829, CM/O45/165). In the same year, a lack of space made it necessary to move the BDS to a larger house, which could accommodate 60 to 80 boys, therefore, the number of children increased remarkably (CMSA: Lieder to Schlienz, June 20, 1828, CM/O73/24). Less than six months after its opening, the school had gained solid ground despite threats of excommunication from Catholic priests. "By our school," wrote Krusé, "we are growing more and more in public reputation. People of all denominations come to know what we are aiming at" (CMSA: Lieder to Schlienz, January 16, 1829, CM/O73/29; Proceed., 1829, p. 231).

The school's objectives were to give poor children an opportunity to learn reading

21 One of the reasons why Krusé preferred this place for opening the school must be the absence of any church or priests in the region, because he writes that "hence the people are less prejudiced than where they are in the midst of chapels and priests and the Patriarch." (CMSA: Müller to Schlienz, December 1, 1834, CM/O73/74).

22 This failure probably resulted from using The Missionary Register as a single source for the author, because this statement was only mentioned in this source (CMSA: Miss. Reg., 1829, p. 235). But there was no information about the superintendence of Kluge in Krusé's letters, which had to be considered as a main and original source (CMSA: Krusé, Müller, Lieder \& Kluge to Jowett, n.d., CM/O73/23; Krusé to Schlienz, October 31, 1828, CM/O73/26). 
and writing and to instruct them in Christianity, but especially to train its most promising students as schoolmasters, so that they could set up and organize other schools in different parts of Egypt (CMSA: Miss. Reg., May, 1832, p. 235; Church Missionary Record, Vol. III, No. 5, May 1832, p. 112; Lieder to Coates, 26 April 1836, $\mathrm{CM} / \mathrm{O} 48 / 13)$. The children came from various Christian denominations, including Copts, Greeks, Maronites, Catholics and Muslims (CMSA: Lieder to Schlienz, June $20,1828, \mathrm{CM} / \mathrm{O} 73 / 24)$. With a few exceptions, almost all children belonged to the poor and much-neglected classes (CMSA: Church Missionary Record, Vol. X, No, 8, August 1839, p. 183; Lieder to the Sec.s of the CMS, April 7, 1841, CM/O48/119), and doubtlessly, many of them would have become beggars in the streets if the missionaries had not supplied them with bread at dinnertime, which enabled them to attend the school more regularly. ${ }^{23}$ Coptic boys were encouraged to use the Coptic language for raising the school's popularity (CMSA: Lieder to the Sec.s of the CMS, January 25, 1839, CM/O45/75b).

The school hours were from 8 a.m. to 12 p.m. and from 2 p.m. to 5 p.m. The schedule was conducted according to the Lancasterian system (CMSA: Miss. Reg., April, 1831, p. 180; Church Missionary Record, Vol. II, No. 4, April 1831, p. 64).

\begin{tabular}{clll}
\hline \multicolumn{2}{c}{ Lessons of the Upper Class/School } & \multicolumn{2}{c}{ Lessons of the Lower Class/School } \\
\hline Morning Hours & Morning Hours & \\
\hline $7.00-8.00$ & Reading of the Bible and explanation & $7.00-9.30$ & Reading and Spelling \\
$8.00-9.30$ & Arabic Writing & $9.30-10.00$ & Breakfast \\
$9.30-10.00$ & Breakfast & $10.00-11.00$ & Writing \\
$10.00-11.00$ & English Writing & $11.00-12.00$ & Counting by head \\
$11.00-12.00$ & Counting by head & $12.00-2.00$ & Dinner \\
$12.00-2.00$ & Dinner & Afternoon & \\
Afternoon & & $2.00-3.00$ & Writing \\
$2.00-4.00$ & Literal Arabic (Nahv) or Grammar Arabic & $3.00-5.00$ & Reading and Spelling \\
$4.00-5.00$ & English reading and speaking & & \\
\multicolumn{5}{c}{ Second Class of the Upper School } & & \\
Morning Hours & & & \\
$7.00-8.00$ & Reading of the Bible with the first class & & \\
$8.00-9.30$ & Reading in the Testament & \\
$9.30-10.00$ & Breakfast & & \\
$10.00-11.00$ & Reading in the Testament & \\
$11.00-12.00$ & Counting by head & & \\
$12.00-2.00$ & Dinner & & \\
Afternoon & & & \\
$2.00-4.00$ & Arabic Writing & & \\
$4.00-5.00$ & English spelling & & \\
\hline
\end{tabular}

The languages taught at the school were the Arabic and Coptic and the system

23 Müller and Krusé had confessed this truth clearly in one of their letters: "If we do not cover their nakedness and satisfy their hunger with bread, neither are we able to instruct them, nor they to receive our instruction." (CMSA: Müller \& Krusé to Brenner, January 26, 1835, CM/O73/73; Müller to Coates, October 15, 1833, CM/O73/79). 
showed a little deviation from that of the British and Foreign School Society (Bartle, 1994), however, the school gained higher esteem because Mr Ayoub taught writing and Arithmetic on paper and on wooden-tablets (CMSA: Lieder to the Sec.s of the CMS, January 20, 1841, CM/O48/120; Church Missionary Record, Vol. XII, No. 8, August 1841, p. 179). The children had 39 lesson hours ${ }^{24}$ during the week: 7 hours for reading the Arabic New Testament and other religious books; 5 for instruction in the Coptic language; 5 for writing; 5 for Arithmetic; 4 for singing Arabic hymns to English tunes; 6 for Christian Catechism; 5 for Sacred History; and 2 hours on Saturday morning for Repetition. Thus, 11 hours were reserved for religious instruction (CMSA: Church Missionary Record, Vol. X, No, 8, August 1839, p. 183; Miss. Reg., May 1845, p. 247; Church Missionary Record, Vol. XVI, No. 5, May 1845, pp. 97-98). The school began and ended with singing and prayer. A chapter of the Old Testament was read in the morning and one from the New Testament in the afternoon. Sunday mornings, from 8-9 a.m., were spent reading a Bible chapter and praying, and for catechization on the Christian or Bible catechism (CMSA: Miss. Reg., August 1839, p. 381; Lieder to the Sec.s of the CMS, March 14, 1845, CM/O48/121). The scholars received religious instruction, which existed chiefly of catechization led by Lieder and assisted by Mr. Yousef, who was the general teacher at the school (CMSA: Lieder to the Sec.s of the CMS, May 20, 1846, CM/O48/122). The younger boys were taught Watt's Catechism and the older boys were made to learn 6 or more verses from the Scriptures. In fact, Lieder did not consider any course material apart from the Scriptures and the History of the Bible to be necessary. According to his view, courses such as Geography, Natural History, Chronology and History would only be taught when the available time and knowledge of teachers were convenient rather than compulsory (CMSA: Lieder to Coates, December 9, 1831, CM/O48/9). Against this background, it could be stated that the schools opened by the Egyptian mission fell behind the idea of modernization that was initiated by Muhammed Ali Pasha; in other words, it was less targeted towards social-cultural transformation than he had been.

Lieder did not find it reasonable to employ a Coptic teacher at the school and believed that a Syrian teacher would be more convenient. Lieder's view on this was a result of the negative approaches that different groups in society had developed against each other. However, he supposed that it was at least possible for people to be objective regarding a Syrian ${ }^{25}$ schoolmaster, as he defined Syrians as the French of the East. ${ }^{26}$ In contrast to Lieder, Krusé believed that the recruitment of a Coptic

24 The number of classes was recorded differently in various reports. For instance, Lieder wrote that there were 47 lessons (CMSA: Lieder to the Sec.s of the CMS, January 25, 1839, CM/O45/75b).

25 "The Syrians who are generally Greek Catholics are merchants, accountants and craftsmen. Some of them fill high stations in the service of the Pasha, and have therefore a great influence among the different Christian sects. They are in general a polite, voluptous, light-minded, less perfidious, but more cunning people, the French of the East" (CMSA: Lieder to Coates, January 10, 1832, CM/O48/10; Miss. Reg., May 1832, p. 227). 
schoolmaster would have brought more children to the school, ${ }^{27}$ but there were none to be found, and Copts usually were obliged to make way -particularly for Syrians- ${ }^{28}$ for other able men and women (CMSA: Krusé, Leider \& Müller to Jowett, February 4, 1828, CM/O73/12; Krusé to Jowett, February 4, 1828, CM/O73/12). Lieder had been to visit Mac Pherson's school in Alexandria and compared his boys to those of Mac Pherson, who was the missionary of the Wesleyan Missionary Society and had founded a station in Egypt before the CMS had (CMSA: Lieder to Coates, August 21, 1826, CM/O48/1). Lieder reported that he encountered a great number of promising boys at the school in Alexandria, an advantage that his own school in Cairo could not boast (CMSA: CM/O73/42), because the boys at the BDS were generally slow in perception and real talent was very rare among them (CMSA: Lieder to the Sec.s of the CMS, January 25, 1839, CM/O45/75b).

The pupils among whom the Copts did not like to study Arabic Grammar (CMSA: "Fares Eshediaks" Remarks concerning the children in the School at Cairo of the year 1832', CM/O73/61) were divided into three classes. The first class read the Old Testament and wrote Arabic and English, the second class did the same but read the New Testament instead (CMSA: Krusé to Coates, January 15, 1834, CM/O45/33) and the third class was instructed only in the Arabic language. In addition, all three classes were taught Arithmetic. The books used for reading were the Bible, Bible doctrine catechisms and other works that always kept the primary objective of the Protestant mission schools in view, namely, to instruct the pupils in the way of salvation.

Krusé, the superintendent of the School, taught the English reading classes himself besides giving the students religious instruction, of which he devoted 4 hours to the Christian Catechism and 4 more to Sacred History, and one additional hour was dedicated to Catechization every Sunday afternoon, beginning and ending with singing and prayer (CMSA: Lieder to Schlienz, June 20, 1828, CM/O73/24). The boys' evening studies consisted of committing their lessons, Catechisms, etc. to memory, and they also prepared the English hymns that were required for the English service on the following Sabbath. Their daily devotions were also conducted by Krusé in the general form of family worship, during which a chapter of the Old Testament

26 "The Muhammedans despised the Copts, and the Copts sought to prevent the Muhammedans from accepting the Society's school" (CMSA: Miss. Reg., December 1832, p. 518; Church Missionary Record, Vol. III, No. 12, December 1832, pp. 276277 Lieder gave the following example of this argument: "A Coptic Monk asked me why I received Muhammedan boys into my school. I replied "Are they not God's creatures as well as you?" "Yes", said he, "but whatever you do for them is a loss". I asked him "Can it be a loss, when we do what our Lord has commanded us to do?" "No", "Well, he has commanded us to go into all the world and preach the Gospel to every creature!” (CMSA: Miss. Reg., April, 1838, pp. 208-209; Church Missionary Record, Vol. IX, No. 3, March 1838, pp. 79-80).

27 It can be understood from the letter he sent to Schlienz on July 12, 1828, that Krusé was right about that issue. For example, seeing that the school had initially opened under the administration of a Syrian called Joseph, which was not preferred, Krusé enquired about the issue and learned that the problem related to the fact that the students did not want a Coptic teacher (CMSA: Krusé to Schlienz, 12 July 1828, CM/O73/24).

28 "Even if Copts would have more capacities, the School would not be better therefore, on account of the Copts being not so free from prejudice and superstition than the Syrians are" (CMSA: Kruse to Schlienz, April 12, 1838, CM/O73/21). 
was read in the morning and one of the New Testament in the evening, for which explanations and exhortations were given (CMSA: Lieder to Jowett, September 9, 1831, CM/O48/7). Mrs. Krusé's importance for the establishment was indisputable in regard to advancing the religious, moral and social progress of the boys; her superintendence of their domestic economy and general comforts in guarding them and correcting their dispositions, and strengthening the habits of cleanliness and kindness in them (CMSA: Lieder to the Sec.s of the CMS, January 25, 1839, CM/ O45/75b; Church Missionary Record, Vol. X, No, 8, August 1839, p. 182; Krusé to Coates, 18 March 1842, CM/O45/109).

Although the school's attendance sometimes reached into the 130s (CMSA: Lieder to the Sec.s of the CMS, March 29, 1847, CM/O48/123), the general mean of the BDS attendance was limited to 55-60 students. In the beginning, the missionaries had tried to explain the low attendance number with the general condition of the children in Egypt and poverty in the country. ${ }^{29}$ Namely, because many people were poor in this country, many of them would not even send their children to a free school. ${ }^{30}$ Moreover, an immense number of boys and girls were employed in the manufactories of the Pasha (Quataert, 2004, pp. 984-987), while others, half naked, carried stone and chalk for buildings all day long, and those who knew how to read and could write a little were employed as the Pasha's scribes (CMSA: Müller, Krusé \& Lieder to Brenner, January 11, 1831, CM/O73/52; Miss. Reg., April 1831, p. 181; Church Missionary Record, Vol. II, No. 4, April 1831, p. 64).

From the time of its opening to September 1828, the BDS afforded instructions to 1530 youths, chiefly children of the poor. Many of the pupils had been respectably employed in the service of the Government, as clerks, copyists and accountants, and had become young adults of their locale who owed their lives to the benefits of their scriptural education. However, the school was closed due to a gradual restriction of Cairo mission's budget in 1848 (CMSA: Miss. Reg., July 1849, p. 316; Church Missonary Record, Vol. XX, No. 7, July 1849, p. 155).

Sislian stated inaccurately that the school was closed in 1847 (1964, p. 200), and it was re-opened for 39 hours of instruction per week on the 1st of October, 1849 with the help of natives, particularly Copts, led by the native school master Muallim Khaleel, one of the former scholars from the Coptic Institution (CMSA: Lieder to the Sec.s of the CMS, February 4, 1850, CM/O48/82; Lieder to the Sec.s of the CMS, August 5, 1850, CM/ O48/88). The number on the books was 96 and the average attendance number was 95 , consisting of 59 Copts, 8 Roman Catholics, 14 Greeks and Armenians, 4 Maronites and 9

29 "Such a troop of half-naked boys we have in our school, and the girls are in no better condition" (Miss. Reg., April 1831, p. 181; Church Missionary Record, Vol. II, No. 4, April 1831, p. 64).

30 Müller complained about the pupils who did not know their own language, thought about nothing except "What shall we eat?" and "Where with all shall we be clothed?"(CMSA: Müller to Coates, October 15, 1833, CM/O73/79; Miss. Reg., January 1836, p. 57; Church Missionary Record, Vol. VII, No. 1, January 1836, p. 9). 
Muslims (CMSA: Lieder to the Sec.s of the CMS, February 25, 1850, CM/O48/125). The languages used, courses, school hours and system were the same as at the former BDS, except for the Coptic lessons, which were replaced by English language lessons because these was thought to be more useful to the boys in their future life, as English interactions would increase the transit of passengers and commerce between India and Egypt, which passed through England. The average attendance number was 85 (CMSA: Miss. Reg., July 1850, p. 305; Church Missionary Record, Vol. XXI, No. 5, May 1850, pp. 104-105). Despite this high number of daily attendance, this school had to be closed within a year due to the financial embarrassment, and in the beginning of 1851 the educational work of the Mission was confined to a single-day school for girls (CMSA: Lieder to the Sec.s of the CMS, April 11, 1851, CM/O48/90; Proceed., 1852, p. xvi; Coldwell, p. 41, 55, 58). The reason for the BDS' closure was not only the lack of financial resources, but also damages caused by the epidemics that relapsed frequently. For example, contagious diseases like influenza, dysentery, ophthalmic and cholera had sometimes been contracted in summer and sometimes in winter since 1828, which caused great interruptions in the educational work (CMSA: Krusé to Coates, August 17, 1831, CM/O45/21) ${ }^{30}$ as has been recorded for the year 1847 (CMSA: Lieder to the Sec.s of the CMS, March 29, 1847, $\mathrm{CM} / \mathrm{O} 48 / 123$ ) and for the year 1848 (CMSA: Lieder to the Sec.s of the CMS, January 27, 1849, CM/O48/124).

Soon after the opening of the BDS, two other schools were established. The first, the Boys' Boarding School (BBS), was opened on 21 November 1833 and regarded as a seminary (CMSA: Church Missionary Record, Vol. V, No. 7, July 1834, p. 143; The Star in the East and Friend of Youth, 29 August 1834, p.3 in CM/O6/15. Also see for Müller enthusiasm with this School CM/O51/14, CM/O51/21, CM/O51/22, CM/O51/25; Church Missionary Record, Vol. X, No, 8, August 1839, p. 181). It was intended for training school masters and catechists and lessons took place under Krusé's supervision in his house for 8 pupils, who were selected from the students of the BDS (CMSA: Krusé to Coates, August 17, 1831, CM/O45/21; Krusé to Coates, October 30, 1833, CM/ O73/63; Krusé to Coates, January 15, 1834, CM/O45/33). ${ }^{31}$ The second one, another Day School for boys, was opened in the year of 1834 under Müller's supervision and in his house, which was located in a different part of the city that was chiefly occupied

30 Education would not start immediately after the removal of danger in the schools, which had been closed due to epidemics, because those that survived the plague had been taken into the Pasha's schools and manufactories (CMSA: Krusé to Jowett, August 25, 1835, CM/O73/77; Church Missionary Record, Vol. VII, No. 1, January 1836, p. 9). For example, the BDS' numbers had reached $70-80$ before being closed due to plague in 1835 , and it was reopened with only 2 students, and two months later this number had only increased to ten. This made superintendent Krusé ask "What has become of the 70 or 80 boys that formerly attended the BDS?" and answered "It is probable that the greatest part of them died of the plague. Some have been taken into the Pasha's Polytechnic School and some have been obliged to seek service in order to earn their bread" (CMSA: Krusé to Jowett, August 25, 1835, CM/O73/77; Church Missionary Record, Vol. VII, No. 1, January 1836, p. 9).

31 Krusé had expressed his excitement in relation to opening this school with the following words: "It is difficult for me to decide who is more anxious, myself or the boys to enter this establishment. Indeed their eagerness to come in gives me much pleasure..." (CMSA: Krusé to Coates, November 20, 1833, CM/O45/31; The Star in the East and Friend of Youth, August 29, 1834, p.4 in CM/O6/15; Church Missionary Record, Vol. V, No. 5, May 1834, p. 75). 
by Copts (CMSA: Müller to Coates, July 30, 1832, CM/O73/59; Müller to Schlienz, 9 June 1834, CM/O37/55a; Müller to Coates, December 30, 1834, CM/O73/73; Miss. Reg., January 1836, p. 57; Church Missionary Record, Vol. VII, No. 1, January 1836, p. 9). The Day School was under the special care of Müller, who taught suitable material to younger boys and also gave them daily religious instructions. Scriptural doctrine was connected with Scriptural history, thus directing the children towards the doctrine as a whole. The same plan was followed for religious instruction at other schools (CMSA: Church Missionary Record, Vol. V, No. 5, May 1834, pp. 75-76; Müller \& Krusé to Brenner, January 26, 1835, CM/O73/73). The main objective of the school was the same as that of other BDS, namely, to train promising boys as schoolmasters who could subsequently organize the Christian schools in different parts of Egypt (CMSA: Lieder to Coates, December 9, 1831, CM/O48/9; Lieder to Coates, January 10, 1832, CM/ O48/10). However, this objective failed, because from the moment the boys could use their knowledge of reading and writing that they had acquired at school their parents took them back so that they could earn money from their new skills, before they could be employed as native missionaries or before religion had made a deep impression on their minds (CMSA: Lieder to Coates, December 9, 1831, CM/O48/9). Lieder, Krusé and Müller had taken some measures to increase the religious impact on the students as much as possible, such as opening the boarding school in the same house where the missionaries lived and, most importantly, charging one person with inspection (CMSA: Lieder to Coates, December 9, 1831, CM/O48/9). Although the first of these measures had been applied since 1831 (CMSA: Lieder to Coates, August 27, 1831, CM/O48/6) and the second one since 1833, the school was unable to achieve its founding objectives.

Attendance at the day schools was irregular, which made it difficult to convey any lasting religious knowledge. For instance, children were often kept away from the school for long periods of time on many Coptic feast days. Another problem was military service. When the Pasha's army required soldiers, young boys were taken from schools to the military schools to be enlisted in the Egyptian army. If pupils could prove to the officials in writing that they were attending a British mission school, they were not taken away (CMSA: Miss. Reg., July 1835, p. 330). Therefore, during such periods, school attendance increased, but would decline again once the threat was over. The boys were also protected against recruitment from factories or other government establishments with such a certificate. "If by mistake one should be taken" Lieder wrote "he was immediately released if we apply to the proper authorities." (CMSA: Lieder to the Sec.s of the CMS, January 25, 1839, CM/ O45/75a; Church Missionary Record, Vol. X, No, 8, August 1839, p. 182).

Müller gave religious instructions daily at his school, and also prepared the boys that showed enough capacity for the Boarding School by giving them an opportunity to learn elements of literary Arabic and English (CMSA: Müller to Coates, March 
$31,1834, \mathrm{CM} / \mathrm{O} 51 / 28)$. However, the exam results showed that the courses had not achieved the targeted impact on the students, and this meant that the education level remained stable and while motivation decreased (CMSA: Müller to Coates, March 31, 1834, CM/O51/28; Miss. Reg., July 1834, p. 313; Church Missionary Record, Vol. V, No. 7, July 1834, p. 144; Miss. Reg., January, 1836, p. 57; Church Missionary Record, Vol. VII, No. 1, January 1836, p. 12). The school had begun education for 25 students, but had to be disbanded in 1837 on account of Müller's departure to Europe. Due to these circumstances and the distance of the school from the mission as well as the lack of sufficient help for its continuation, Krusé and Lieder were obligated to close it (CMSA: Lieder to the Sec.s of the CMS, January 25, 1839, CM/O45/75a).

Lieder had gained a more important status in the mission since the departure of Müller and became the leading missionary for CMS's gradual educational work in Cairo. For example, Lieder became the superintendent of the BDS that had been opened and administered by Krusé until $1835,{ }^{32}$ after that respective year (CMSA: Lieder to the Sec.s of the CMS, January 25, 1839, CM/O45/75b; Knoth to Coates, June 20, 1836, CM/O8/31). Thus, Krusé's responsibilities in educational work were limited to seminary duties only (CMSA: Lieder to Schlienz, January 25, 1836, CM/O73/80).

However, a considerable delay arose for obtaining suitable premises for carrying out plans for the BBS. Because more space was needed, the school and Krusé's family were transferred to a bigger house a short while after its opening (CMSA: Krusé to Coates, October 30, 1833, CM/O73/63) and the number of boarding students increased to 20 in six months (CMSA: Isenberg to Coates, April 8, 1834, $\mathrm{CM} / \mathrm{O} 73 / 67)$. However, the average attendance was $10-15$ over the course of 8 years. The main objective of the seminary was to train schoolmasters, and for that purpose the pupils were instructed in literary Arabic, reading and writing, Composition, Arithmetic and Geography. They also received one hour lessons in English everyday, which would not only enable them to better understand their own Grammar, but also to read English tracts and books in the future. Moreover, it showed which students exhibited a capacity for translation. However, the principal part of the instructions had always been religious, given by Krusé himself, intended to acquaint the students with the doctrines of the Bible and with Church History. The pupils were also subject to Krusé's constant inspection, who lived in the same house with them and attended their morning and evening prayers. As a result, Christian principles were imprinted upon the students' minds in whatever they did, whether they were learning in the school or doing other things in their leisure hours (CMSA: Miss. Reg., May 1834, p. 224; Church Missionary Record, Vol. V, No. 5, May 1834, pp. 75-76). The missionaries' aim was to influence the Coptic Church through the Coptic students at

32 With the exception of two years, namely 1832 and 1833, when it was conducted by Müller (CMSA: Lieder to the Sec.s of the CMS, January 25, 1839, CM/O45/75b). 
this seminary. The greatest emphasis was given to making the seminarists into "true Christians," or else the work would be considered in vain. To ensure that they were truly converted, the seminarists were supervised very strictly during their work and leisure hours (CMSA: Miss. Reg., 1834, pp. 223-225).

All boys rose at day-break, washed and dressed, and then studied their lessons, especially Biblical Catechism, until 7 a.m., when the family service was held, during which Krusé read a chapter from the Old Testament and occasionally accompanied it with some practical remarks. Then it was time for breakfast. At 8 a.m., the headteacher came to give instructions until lunch-time at $12 \mathrm{p} . \mathrm{m}$. After this, the students were free until 2 p.m., after which the head-teacher continued the instructions until 5 p.m. They then had a half an hours' leisure, after which they had to commit and prepare their lessons. Supper was served at 7 p.m., after which the boys were again to study their lessons until 8 p.m., when Krusé held the Evening Service with them. During this service he would read a chapter from the New Testament. After the Evening Service, which usually lasted until 9 p.m., although sometimes a little longer, everyone went to bed.

The students were not allowed to go out, except to take a walk with their teachers, or to visit their relatives by special permission from Krusé. However, it was difficult to keep them in the school on feast days, during which most Copts would take their children out of the school for a considerable time, taking them along to the marketplace where they often forgot most of what they had acquired at school (CMSA: Miss. Reg., July 1835, pp. 330-331). Every student in turn was made senior for a week, whose duty it was to preserve order and cleanliness by being responsible for the transgression of all regulations. Two others were appointed as famuli, likewise alternately for a week together, whose duty was to sweep the school-room and dormitory every morning, to serve at the table, and to clean up after meals.

However, the pupils' denominations had gradually become more cosmopolitan, and Muslim families particularly began to show their interest in the seminary. For example, there were no Muslim boys at the school at first, but later many applied, viz. 9 Muslims, but the mission's limited funds did not permit the missionaries to increase the number of scholars at the BBS..$^{33}$

The pupils were mainly children of poor parents and orphans (CMSA: Lieder to the Sec.s of the CMS, January 20, 1841, CM/O48/120; Church Missionary Record, Vol. X, No, 8, August 1839, p. 182; Church Missionary Record, Vol. XI, No. 5, May 1840, p. 102), and they were divided into two classes at the seminary. The first class consisted of 11 pupils in the year 1841, who received 47 lessons weekly on the

33 The number of boarding students was limited to 14 even two years after the opening of the school (CMSA: Müller \& Krusé to Brenner, January 26, 1835, CM/O73/73; Church Missionary Record, Vol. XI, No. 5, May 1840, p. 102; Coldwell, n.d., p. 41). 
following subjects. In Arabic, they received 8 hours religious instructions in the larger Christian Catechism and in Scripture History, 4 hours instructions in Grammar, 2 hours in writing Compositions, 2 in Bible reading according to grammatical pronunciation, 3 hours in Geography, 3 hours in Arithmetic, 3 in Drawing, 2 in Universal History, 2 in Church History, and 3 hours in Theoretical singing. In English, they received 5 lessons in Calligraphy, Orthographical exercises and Drawing (CMSA: Church Missionary Record, Vol. X, No. 8, August 1839, p. 182; Church Missionary Record, Vol. XI, No. 5, May 1840, p. 102; Lieder to the Sec.s of the CMS, January 20, 1841, CM/O48/120), 5 lessons in Grammar, and 5 in reading the New Testament, which was explained to them in Arabic and translated into Arabic by them. Since the beginning of the year 1841, the elements of Geometry and Astronomy had been added to their studies by one European and two native teachers (CMSA: Lieder to the Sec.s of the CMS, January 20, 1841, CM/ O48/120; Church Missionary Record, Vol. XII, No. 8, August 1841, p. 179). This class also led the Church singing on Sundays, and two of the older boys joined in reading the Psalms and Responses of the Liturgy in English. The other boys of this class also committed to memorize all Catechisms that had been printed at Malta (Kocabaşoğlu, 1988, pp. 267-286). The second class consisted of 13 pupils in 1841, and they also received 47 lessons weekly. In Arabic, they received 8 hours religious instruction in the smaller Catechisms on Religion and Scripture, 6 hours in the rudiments of Grammar, 10 in reading the New Testament, 4 in Arithmetic, 5 in Caligraphy, and 5 hours of reading and translating spelling lessons of the British and Foreign School Society (CMSA: Krusé to Coates, January 15, 1834, CM/O45/33; Church Missionary Record, Vol. XI, No. 5, May 1840, p. 102; Lieder to the Sec.s of the CMS, 7 April 1841, CM/O48/119). Sometimes other boys and their fathers participated in these instructions at the seminary, which proved that the people's prejudice against the missionaries had diminished (CMSA: Miss. Reg., July 1834, p. 312; Church Missionary Record, Vol. V, No. 7, July 1834, p. 142; Church Missionary Record, Vol. X, No, 8, August 1839, p. 181). Thus, the seminary was not limited to boarding students. From the beginning, it had also been open and beneficial to other pupils that could not be received at the school on account of the prescribed funds, or because of some deficiency in their ability, or because their parents would not give their permission for them to enter. Thus, a considerable number of children besides the regular boarding students, several of whom were the children of Christian parents of Cairo's highest rank, enjoyed the benefits of this seminary (CMSA: Lieder to the Sec.s of the CMS, January 25, 1839, CM/O45/75b; Church Missionary Record, Vol. X, No, 8, August 1839, p. 182). The school also served as a kind of public education centre, like the madrasas (Islamic high schools), as on Sundays parents would occasionally come to the school for the purpose of attending the Divine Service that was imparted by Müller (CMSA: The Star in the East and Friend of Youth, August 29, 1834, p.4 in CM/O6/15).

Instructions for mental improvement were conducted by four teachers at the 
Boarding and Day School for boys. The first and general teacher was Mr Ayoub, a Syrian, who taught Arabic reading, writing, Arithmetic and Universal History, and who also attended to the pupils' Arabic compositions and always accompanied them on their excursions. As he was a Roman Catholic, Krusé would not have chosen Mr Ayoub or kept him on for such a long time, if a better candidate could have been found. The second teacher was Mr Barthelemy, who was an Egyptian by birth but of French origin, who had been made the first teacher in 1841 (CMSA: Krusé to the Sec.s to the CMS, 1839, CM/O45/76) and had been sent to France for his education. He gave instructions in Geography, using globes, drawing, English writing and Arithmetic. Mr Barthelemy was the most meticulous as compared to the other teachers and he was open-minded towards improvements according to the missionaries. The third teacher was Mr Metri, a youth educated at the seminary. He belonged to the Greek Church, and gave lessons in Theoretical singing. The fourth teacher was Sheik Hasan, a Muslim who was employed for the purpose of giving instructions in Arabic Grammar (CMSA: Lieder to the Sec.s of the CMS, January $25,1839, \mathrm{CM} / \mathrm{O} 45 / 75 b)$. Lieder's department at this school, particularly since 1837 , besides his general superintendence over its teachers and pupils, was to guard the students' moral conduct, to watch over their spiritual interests and to give them Scriptural instructions on the Sabbath morning (CMSA: Lieder to the Sec.s of the CMS, January 25, 1839, CM/O45/75b).

The seminary, under Krusé's supervision, which was pursuing different kinds of instruction, was favorably countenanced by the natives and was also noticed by the Government. For instance, Sheik Rifat, who had been educated in France and who was the principal of the Government Institution for Language Study, visited the seminary in 1834 and was so delighted with the order and progress of the boys, especially in Arabic Grammar, that he said he would beg Muhammed Ali Pasha to allow him to open a similar establishment (CMSA: Miss. Reg., July 1835, p. 331; Church Missionary Record, 1835, p. 144; Krusé to Coates, June 30, 1836, CM/ O45/176; Church Missionary Record, 1836, p. 11; Lieder to the Sec.s of the CMS, January 25, 1839, CM/O45/75b). In the same year, Colonel Campbell, who was the political representative of the British Empire in the Pasha's dominion, examined some students at the seminary during his participation in the Divine Service, and expressed his great surprise and satisfaction about their knowledge of the English language (CMSA: Miss. Reg., July 1835, p. 332).

On 18 December 1839, the Egyptian Minister of Public Instruction, Adham Bey, examined the CMS schools together with other Egyptian officials, Hekekyan Bey and two engineers. They examined the boys in a Geography class by using a globe and also examined their Arabic writing. They took notes and made enquiries about the Lancasterian system, because they intended to start a similar school for the 
Government (CMSA: CMS Records, Vol. XI, 1840, pp. 103-104). They asked about the books that were used by the seminary, the parents' reactions to the Bible readings and the social backgrounds of the pupils, and expressed their satisfaction with the work that was being done at the schools. After this inspection, Adham Bey not only opened a Lancasterian School in the centre of the town, but also an infant school, which was probably the only example of a school in the East during that period that made use of the British system for both sexes (CMSA: Miss. Reg., August 1841, p. 380; Church Missionary Register, Vol. XII, No. 8, August 1841, p. 181). As indicator of the appreciation of the works carried out by the missionaries, Adham Bey made an offer to the missionaries to get any schoolbooks they wanted in Arabic or English printed for them by the Pasha's press (CMSA: Krusé to Jowett, December 20, 1839, CM/O45/82; Lieder to the Sec.s of the CMS, March 13, 1840, CM/O48/30a; Church Missionary Record, Vol. XI, No. 5, May 1840, pp. 103-104). From that time on, spelling books and Atlases printed at Malta (CMSA: CMS Records, Vol. VII, 1836, p. 11; Jowett, 1822, pp. 314-315) were given in large numbers to the Egyptians to use in their schools. ${ }^{33}$ On the one hand, this had been effective for the missionaries' safe execution of their educational activities; however, it created a new income resource for the mission. ${ }^{34}$

A remarkable example of the Government's generous liberality was the fact that not only all boys at the seminary had been protected against recruitment for Government establishments that year, but also those that had already left the school, if they could prove that they had been educated at the mission school, were protected. "There is no country" expressed Lieder, "so favorable for missionary operations as Egypt, where missionaries are permitted and countenanced by Government with such liberality" (CMSA: Lieder to the Sec.s of the CMS, March 17, 1840, CM/O48/119). Not only government officers had been satisfied with the CMS schools in Cairo, but also natives were of the opinion that these schools were superior to the others. In the beginning, only children from families of very low socio-economic backgrounds had attended, but gradually children from wealthy Coptic families also began to attend the schools, and the overall number of students increased to 214 in 1843 and to 316 in 1844 (CMSA: Miss. Reg., May 1845, p. 247; Church Missionary Record, Vol. XVI, No. 5, May 1845, p. 97).

However, the principal difficulty that the missionaries encountered in running

33 For example, Krusé had presented one Atlas to Mr Hekekyan on August 28, 1835, and received an order for another 50 copies (CMSA: Church Missionary Record, Vol. VII, No. 1, January 1836, p. 9; Miss. Reg., August 1841, p. 380; Church Missionary Register, Vol. XII, No. 8, August 1841, p. 181).

34 The Malta Press was set up in 1827 by the CMS and played an important role in printing books for the use of missionaries (Jowett, 1822, pp. 314-326; Joint Committee on the Survey of Christian Literature for Moslems, 1923, p. 50). The Society's religious schoolbooks were introduced into several Coptic Schools, the Armenian School had an ample supply, and the Jews' School had been partially provided with Hebrew and French Bibles, thus the usefulness of the missionaries increased through those publishments (CMSA: Krusé to Coates, November 10, 1841, CM/O45/77; Miss. Reg., June 1842, p. 289). 
the schools was the lack of competent schoolmasters. Some pupils worked as schoolmasters, and were examples to others (CMSA: Miss. Reg., April 1831, p. 180; Church Missionary Record, Vol. II, No. 4, April 1831, p. 64) ${ }^{35}$ However, the teachers' salaries were significantly lower than the salaries paid to government teachers and even lower-rank officers. ${ }^{36}$ This moved the missionaries to warn the Committee that some qualified teachers would leave the school if their salaries would not be increased (CMSA: Krusé to the Sec.s of the CMS, 1839, CM/O45/76), however, these warnings were not effective. Another obstacle was the fact that the children, among whom some were Muslims, ${ }^{37}$ generally suffered from staying only a very short time at the schools, even though almost every boy that was admitted had been brought to the school by his father or mother in full confidence, with the following words to the teachers: "This boy is your son, do with him as you like" (CMSA: CMS Record, Vol. IV, 1832, pp. 112-113; Miss. Reg., May 1832, p. 235). However, their promises were mostly vain words (CMSA: Miss. Reg., May 1832, p. 235; Church Missionary Record, Vol. III, No. 5, May 1832, p. 113; Church Missionary Record, Vol. III, No. 12, December 1832, p. 277), for as soon as the boys knew how to read and write a little, their parents would take them out of the school, because they wanted their help in making a living (CMSA: Müller, Krusé \& Lieder to Brenner, January 11, 1831, CM/O73/52). Therefore, Krusé, Müller and Lieder tried to keep boys that showed promise of becoming able schoolmasters by means of a small remuneration, equivalent to what they might have been able to earn elsewhere, and were thus able to continue their education (CMSA: Miss. Reg., April 1831, p. 181; Church Missionary Record, Vol. II, No. 4, April 1831, p. 64).

It is interesting to note that Muslim pupils did not object to instructions in the Christian religion and never demonstrated their difference of religion as they attended morning and evening prayers regularly and sang Christian hymns (CMSA: Krusé to Coates, January 24, 1838, CM/O45/61; Krusé to Coates, March 21, 1838, $\mathrm{CM} / \mathrm{O} 45 / 63)$. In fact, the missionaries were surprised by the many applications of Muhammedans, because when a boy entered the seminary, the first thing they learned, besides the usual daily instructions, was the Lord's Prayer, then the Creed and 10 commandments, and after this the Catechism lessons would begin (CMSA: Krusé to Coates, March 21, 1838, CM/O45/63). However, this did not last long, as two Muslim students were taken into custody for a while when they were enrolled at the school in 1840, when Egypt's international relations were tense (McGregor, 2006, pp. 117-120, 173-175; Weigall, 1915, pp. 74-77). This affected other families

35 The great need of a competent teacher was also a problem for the Girls' Day School. See Church Missionary Record, Vol. II, No. 4, April 1831, p. 64.

36 "A poor clerk" a native said, "who can do nothing more than copy accounts, receives from the Pasha 25 to 30 dollars, besides two changes of raiment a year - food for the ass, \&c." On the other hand, the monthly salaries that were given to teachers were about 10 dollars (CMSA: Krusé to Schlienz, June 20, 1829, CM/O73/30; Miss. Reg., January 1830, p. 69).

37 In the year 1837, of the seminary's 10 boarding students, four were Muhammedan and three were Copts (CMSA: Krusé to Jowett, October 4, 1837, CM/O45/58). 
negatively and the number of Muslim pupils at the school decreased rapidly (CMSA: Krusé to Coates, September 10, 1840, CM/O45/89; Church Missionary Record, Vol. XII, No. 8, August 1841, p. 178). After this incident, Krusé became cautious for a while in admitting Muslim students to the school (CMSA: Krusé to Coates, July 14, 1842, CM/O45/113).

The fact that the number of students at the seminary had a potential for increasing in the 1840s can be derived from Krusé's correspondences, in which he states that there was much demand both from Copts and Muhammedans (CMSA: Krusé to Coates, March 21, 1838, CM/O45/63; Krusé to Coates, January 24, 1838, CM/O45/61). However, this respective success was apparently not protected over a longer period of time and neither the seminary nor the day-school had a positive reputation in 1842 . The situation was such that there were only three Coptic boys at the boarding school. The failure of the school was related to the fact that the promised English assistant had not been sent (CMSA: Lieder to the Sec.s of the CMS, December 26, 1842, CM/ $\mathrm{O} 48 / 52$ ), for which the most frequently used excuse was the fact that the missionaries were too busy to carry out continuous inspections (CMSA: Krusé to Coates, January 15, 1834, CM/O45/32; Krusé to Jowett, October 4, 1837, CM/O45/58; Krusé to Coates, January 22, 1839, CM/O45/71). On the one hand, the families' expectation that the school would fulfil all of the students' boarding requirements had gradually increased the mission's workload (CMSA: Lieder to Coates, January 8, 1843, CM/ O48/53). Moreover, the provision for the graduates' employment was among the families' expectations and Krusé was worried that the school would lose its practical value and meaning if a clear solution would not be found for that issue. ${ }^{38}$ The school had ultimately changed into a Coptic Seminary/Institution in 1843, keeping only three Coptic youths to be trained as Coptic Clergy (CMSA: Lieder to the Sec.s of the CMS, March 14, 1845, CM/O48/121; Stock, Vol. I, 1899, p. 351), for which Egyptian boys of the Coptic Church received a scriptural education intended for their ordination as ministers of that Church (Coldwell, n.d., p. 40).

\section{Girls' Schools}

The missionaries found that the subject of female education was entirely neglected and needed particular attention in Egypt. ${ }^{39}$ However, they were told that Christians would not send their girls to the school out of fear that once they could read and write, they would do nothing but write and receive letters (CMSA: Miss. Reg., May 1829, p. 234; Church Missionary Society, 1910, p. 23). Nevertheless, Mrs Dussap,

\footnotetext{
38 "If we cannot employ them" says Krusé, "thus my labour seems to be in vain" (CMSA: Miss. Reg., April 1838, p. 208; Church Missionary Record, Vol. IX, No. 3, March 1838, p. 79).

39 In this respect, Lieder's impressions of the region as a result of his contacts are important: "I found five ladies who could read, to whom I presented Bibles, in order to encourage reading among the females, but among the Copts I never found one" (CMSA: Miss. Reg., May 1832, p. 229).
} 
a negress and ex-slave (Sislian, 1967, p. 192) and wife of a French doctor who was in charge of the Pasha's Army Medical Service at Aswan (Heyworth-Dunne, 1939, p. 113, 124), advised the missionaries that the Arabs would send their daughters to the Girls' School if the girls would be taught sewing and knitting as well as other subjects, even though it would be difficult in the beginning, as they would think that the missionaries would gain benefits for England from their own country (CMSA: Miss. Reg., May 1829, p. 234). Despite this, the missionaries believed that once the daughters of one generation were trained, the character of the next generation would already be indelibly and positively fixed. Therefore, on 24 January $1829,{ }^{40}$ the first Girls' Day School (GDS) in Egypt was opened in Cairo under the supervision of Mrs Krusé (CMSA: Miss. Reg., 1829, p. 308; Krusé to Coates, 30 June 1836, CM/ O45/176). Mrs Krusé reported that she had tried in vain to start a Girls' School for a long time, as the Franks generally had an ill name among the Arabs, and that only after the Boys' School was opened and the Arabs had been able to observe what was being done, they were inclined to send their daughters to her school.

The opening of a Girls' School was an important step forward in the Society's missionary field in Egypt. At first, the GDS consisted of 9-10 girls (CMSA: Lieder to Schlienz, February 21, 1829, CM/O73/29), from 5 to 7 years of age, of whom eight were Copts and two Muslims, and all so poor that they were hardly able to clothe themselves adequately. Only two Muslim pupils brought their own bread. Mrs Krusé began her instructions with teaching them how to read and sew, as no girls would come to the school for reading alone because their parents doubted what merit could be gained from this acquirement. For this reason, they only learned to read in order to learn sewing at the same time. However, Mrs Krusé believed that, once they would perceive the great benefit that reading would give them, they would consider the latter as secondary instead (CMSA: Krusé to Schlienz, August 12, 1829, CM/O73/24; Proceed., 1830, pp. 73-74; Church Missionary Record, Vol. I, January 1830, p. 13; Miss. Reg., May 1829, p. 234; Miss. Reg., July 1829, p. 308). Mrs Krusé reported this issue as follows:

"At first the girls enjoyed learning the Alphabet, but one girl told me that her mother was opposed to her learning to read. I replied that 'All those who will to come here into my school must learn to read the Bible; whoever will not to do this, I cannot receive'. Hearing this she was immediately willing for the sake of learning to sew, to learn also to read." (Young, 1927, p. 28). The school did not achieve remarkable success, because Mrs Krusé had to leave frequently due to health reasons, and gradually lost its function (CMSA: Krusé to Brenner, October 30, 1830, CM/O48/53) after a new GDS was

40 Although the opening date of the school is written as 6 February 1829, in the Missionary Register (CMSA: Miss. Reg., July 1829, p. 308) we prefer to consider the letters written by the missionaries (CMSA: Krusé to Coates, June 30, 1836, $\mathrm{CM} / \mathrm{O} 45 / 176$ ). 
opened under the administration of Mrs and Mr Lieder (CMSA: Church Missionary Record, Vol. X, No, 8, August 1839, p. 181), and it was closed in 1835.

The new GDS under the administration of the Lieders, which was located in the Coptic quarter in a house adjoining Lieder's (CMSA: Miss. Reg., May 1845, p. 247; Church Missionary Record, Vol. XVI, No. 5, May 1845, p. 98; Church Missionary Monthly Paper, August 1829, p. 1 in Hp 35), was quite different from the previous school. The number of students had increased from 10 to 85 and children from respected families had started to constitute the majority of pupils (CMSA: Church Missionary Record, Vol. XII, No. 8, August 1841, pp. 179-180). This affected the quality of the education positively and the girls' graphic of success was higher than that of the boys (CMSA: Lieder to Schlienz, January 25, 1836, CM/O73/80; Church Missionary Record, Vol. XII, No. 8, August 1841, p. 180). The school's success encouraged the Catholic Greeks to take action against it. They attempted to seduce the headmistress, but did not succeed. Subsequently, the head of that Church announced that they would open a Girls' School of their own. On hearing this, Lieder expressed his joy with confidence, saying that he was ready to withdraw as soon as the CMS's school would be rendered superfluous by them. Lieder also offered them any kind of service or material for the organization of the school, if they wished it (CMSA: Lieder to Schlienz, January 25, 1836, CM/O73/80). However, three years later, the GDS suffered a great decrease of its pupils twice, particularly of those belonging to the Greek Catholic Church. In 1838, the Patriarch of that Church threatened parents with excommunication if they continued to send their daughters to the school. However, because Lieder was individually known to all the families from his medical practice, the Patriarch encountered much opposition and many defenders of the school, and as a result the persecution was soon renounced, and almost all girls returned to their old quarters (CMSA: Miss. Reg., August 1839, pp. 381-382).

The school's system and schedule of teaching was the same as those of the Day School for boys with the exception of Saturdays, when there was no school, as the girls were required to be at home to help their mothers with domestic duties. They had 35 lesson hours weekly, of which 20 were conducted in the morning, for mental instruction, and 15 in the afternoon, for Native and European Sewing and Embroidery. They received mental instruction in the forenoon. They were taught in Arabic, however, a few of them were also given lessons in English (CMSA: Miss. Reg., May 1845, p. 247; Church Missionary Record, Vol. XVI, No. 5, May 1845, p. 98; Church Missionary Monthly Paper, August 1829, p. 1 in Hp 35). Every week, in the morning, 6 hours were devoted to reading, 3 to Arithmetic on common lesson-boards, 3 to writing on wooden boards, 3 to Sacred History, 3 to Watt's Catechism, and 2 to the explanation of doctrinal parts of the Bible and Catechization, which meant they received 8 hours of religious instruction every week. The pupils showed much interest in sewing and embroidery 
classes. Probably, both parents and daughters recognized the commercial value of the needlework and embroidery that was taught in the school.

Three teachers were employed by this school. The first was Um Suliman, a Syrian by birth and education, who imparted mental instructions. The other teachers were sisters, Anna and Barbara, who were of the Coptic Church. They were employed to supervise the sewing and embroidery classes in the afternoon. Mr Ayoub also gave advanced-level lessons in writing and Arithmetic to a separate class that was especially intended to train the students to be able and active school-mistresses (CMSA: Church Missionary Record, Vol. XII, No. 8, August 1841, pp. 179-180). Lieder's chief office in the GDS supervised the religious lessons given by Um Suliman, and he taught two hours himself every week in addition to those, namely one lesson on Monday and another on Thursday, to explain the doctrinal parts of the Sacred Volume and Catechization (CMSA: Lieder to the Sec.s of the CMS, January 25, 1839, CM/ O45/75b; Krusé to Coates, November 10, 1841, CM/O45/77). Mrs Lieder's duty was to supervise the general order of the system as a whole, besides attending to the children's cleanliness and morals. As the school was located in Lieder's own house, she was able to spend the greater part of the day in the school-room, except on Mondays and Thursdays when she regularly gave instructions at the palace of the Pasha from 9 a.m. to 1 p.m. (CMSA: Church Missionary Record, Vol. X, No, 8, August 1839, p. 184; Church Missionary Record, Vol. XII, No. 8, August 1841, pp. 179-180).

The GDS's average attendance number was 65 . The GDS stood apart from the other schools in terms of attendance in its significant difference between the number of enrolled students and those who attended regularly. The causes of the daily absence of so many students were certain Eastern customs, such as the frequent use of the baths, to which mothers generally took their daughters, the long visits that they made and received, and the frequenting of gardens for health or pleasure. On all these occasions, an Eastern mother would not be happy if her children were not with her (CMSA: Krusé to Coates, June 17, 1836, CM/O45/48; Miss. Reg., August 1839, p. 381; Church Missionary Record, Vol. X, No, 8, August 1839, pp. 183-184; Lieder to the Sec.s of the CMS, March 14, 1845, CM/O48/121).

As in most missionary schools, the GDS's appearance was marked by the rich diversity of its students. In 1836, for instance, two-thirds of students were from Greek, Greek Catholic and Maronite families and one-third from Coptic families. Thus, Lieder managed to introduce mutual instruction at the GDS according to the Lancasterian school system. ${ }^{41}$ One particular advantage of this system of mutual instruction was the abolishment of the unprofitable practice of teaching children only from ecclesiastical

41 The inward Lancaster form, i.e., by mutual instruction, had been pursued from almost the beginning; however, not much attention was paid to the outward form in order to save expense (CMSA: Krusé to Coates, April 30, 1838, CM/O45/47). 
books. Hundreds of poor girls were uplifted by the education they received, and their knowledge, usefulness and general conduct marked them as superior girls, many of whom were called to teach from house to house and thus, put to shame the ignorant daughters of the rich. The moral conduct of the girls was satisfactory in general, and many of them were used to read with their parents and neighbors in the evening, a thing formerly not thought of in Egypt. Change was visible during those years, for Mrs Lieder received applications from some of the first and wealthiest families in Cairo (CMSA: Lieder to the Sec.s of the CMS, May 20, 1846, CM/O48/122). "When this school" Mr Lieder wrote "was opened by me there was no Egyptian lady existing, who could read or write, and since that time have more than 300 pupils left this School, who are at least now able to read the word of God and other useful educational works." The school soon became the most pleasing and attractive component of the mission, beyond expectation, and its number of pupils steadily increased every year. By the end of 1836, it had increased to 105 , and at the close of 1838 the school contained no fewer than 144 pupils. Interest was shown by the Roman Catholics and Orthodoxes in Cairo, which increased particularly after the opening of a high class at the Lancasterian School, to which many Roman Catholic Nuns, Sisters of the Order of the Bon Pasteur, and other women were sent from Rome for educational purposes (CMSA: Miss. Reg., July 1847, p. 305; Church Missionary Record, Vol. XVIII, No. 5, May 1847, p. 107).

An attempt was made to organize the Lancasterian school like those in England. The children began with learning the Alphabet and advanced step by step until they could read portions of the Scriptures from the lesson boards (Aksu, 2008b, pp. 29-67). They were also taught Arithmetic, and as soon as they finished this course they were promoted to the high class. Parts of Watt's Catechism were read to them every day, which they had to repeat. The high class was initiated to the especial purpose of training students as able and competent teachers, not only for the present school, but also to serve as instruments for Society as part of future school enterprises (CMSA: Lieder to the Sec.s of the CMS, January 25, 1839, $\mathrm{CM} / \mathrm{O} 45 / 75 b$ ). In this class, students read the Old and New Testaments, wrote on paper or varnished boards or slates, and were taught to keep an account of household expenses and some successful girls in turn assisted the Lancasterian school as monitors.

However, the school considerably suffered during the course of 1847, first due to the cholera epidemic, of which many of its pupils had died; and later due to the Government's attempt to recruit girls for employment in the service of the Pasha, which made parents prevent their daughters' attendance at the school, particularly if they lived at some distance from it (CMSA: Miss. Reg., July 1849, p. 316; Church Missionary Record, Vol. XX, No. 7, July 1849, p. 155). As a result, the number of pupils had decreased to 70 (CMSA: Miss. Reg., July 1850, p. 305; Church Missionary Record, Vol. XXI, No. 5, May 1850, p. 105). 
The possibility of raising the position of women in Egypt was of interest to the female CMS missionaries. Essentially, their presence significantly reinforced this trend in missionary activities towards practical concerns of women's welfare (Semple, 2003). Female missionaries taught the daughter of the Pasha and a number of his Harem (Sislian, 1967, pp. 198-199). In fact, this idea had been brought forward by Egyptian statesmen who were very different from the missionaries, and it was also supported by the Harem. For example, Hekekyan Bey, the Director of the Polytechnic School, who had received his education in England and became a keyfigure as the Minister of Education in the Pasha's educational programme (CMSA: Müller to Coates, October 15, 1833, CM/O73/79), helped to direct attention to female education (CMSA: January 18, 1840, CM/O48/30b; Krusé to Jowett, November 25, 1837, CM/O45/59). ${ }^{42} \mathrm{Mr}$ Hekekyan proposed that Mrs Lieder would give lessons to his daughters in the Harem, and as a result an important enterprise was initated, which continued until 1840, and its political reflections were observed (CMSA: Krusé to Coates, November 25, 1837, CM/O45/59). The introduction of elementary instructions into the Harems created an appetite for further education. These women received their first impressions of infancy and childhood in the Harem, which meant that the importance of early intelligent instructions could not be overestimated. Once education was provided in the Harems, it followed more easily beyond its walls. Like Mr Hekekyan, Miss Nazly, the eldest daughter of the Pasha, was interested in the education for girls and wrote a letter with the title "To the most honorable members of the Society" dated December 30th, 1838. This letter, full of gracious expressions and signed by the most important members of the Harem ${ }^{43}$ clearly displayed CMS' impact on the improvement of women's education in Egypt:

"The philanthropy which you manifested in favor of the instruction and education of the females of our countries, has filled our hearts with tender emotion, your approbation of the feeble degree of effort and zeal which have been employed by us towards the same object has encourages us, and the testimonials of affection which you have vouchsafed to present us have pleased us." (CMSA: Nazly \& Zeineb Hanum to the CMS, December 30, 1838, CM/O48/25c). In 1840, Miss Nazly founded the Egyptian Society for Promoting Female Education in the dominion of the Pasha for the purpose of increasing the life standards of women.

To this purpose, Mrs Lieder was employed at the Harem of the Pasha from May 1838 (CMSA: Lieder to the Sec.s of the CMS, March 13, 1838, CM/O48/23). Although the

42 There was someone whom the missionaries called Sheich Rafaà (Director of School for Training Translators) and who had completed his education in Paris among other Egyptian statesmen, who paid great attention to the education of Muslim girls and wanted to make it his duty to bring Muhammedan girls into the female school (CMSA: Müller to Coates, October 15, 1833, CM/O73/79).

43 It was signed by the eldest daughter of Nazly Hanım, the youngest daughter of Zeineb Hanım, the lady of Ibrahim Pasha, the younger lady of Ibrahim Pasha, the lady of Tosun Pasha, the lady of Abbas Pasha, the lady of Ismael Pasha and the lady of Ahmed Pasha (CMSA: Nazly \& Zeineb Hanim to the CMS, December 30, 1838, CM/O48/25c). 
missionaries' direct interference was avoided, they were hopeful that it would gradually open doors in every direction for direct missionary operations. The attendants of these Harem classes were the daughters of Muhammed Ali Pasha, those of Ibrahim Pasha and of his other near relations, a total of 100 children (CMSA: Krusé to Coates, March 21, 1838, CM/O45/63). ${ }^{44}$ Mrs Lieder taught every day at first, later twice in the week, ${ }^{45}$ from 9 a.m. to 12 a.m. in the morning, giving instructions in manual occupations such as sewing and embroidery (CMSA: Lieder to Lieder, January 21, 1839, CM/O48/25b) ${ }^{46}$ in the Palace of the Pasha's daughter, by special invitation of Muhammed Ali Pasha. Lieder hoped that respective improvement would be meaningful not only for the improvement of female education in Egypt, but also for the missions. Indeed, before completing one year, in Lieder's words, "Pasha was extremely affected at the piety and philanthropy of the English ladies composing the society for the promotion of female education in the East" and he recommended Nazly Hanım and the Princesses of his family "to follow their example in his dominions" (CMSA: Lieder to Lieder, January 21, 1839, CM/O48/25b). It is impossible to estimate the full extent of the beneficial results that followed from the female missionaries' attempts to educate women in the higher classes of the society. One remarkable result was the indication that the Pasha would entrust the education of his younger sons to the care of a missionary. Lieder had referred the necessity of sending someone-for instance, Mr Pfander or Mr Fjellstedt-from the Basel Missionary Society to the Egypt immediately for realising this request (CMSA: Lieder to Mrs Lieder, January 21, 1839, CM/O48/25b; Lieder to Jowett, December 20, 1838, CM/O48/25a), however, his suggestion was never taken into consideration. ${ }^{47}$ On one hand, this caused an interruption in the GDS' work according to the Lancasterian system for a while. On the other hand, the GDS appeared to have a better reputation than the Boys' School, as a number of girls came from influential Coptic families. However, the fact that the girls were betrothed and married very early, between their 9th and 11th year of age, according to custom, was a great disadvantage to the GDS. "Once betrothed or married," wrote Lieder, "a girl is no longer allowed to appear in public. In consequence of this custom, we lost last January no fewer than 11 of our most helpful pupils." (CMSA: CMS Record, Vol. X, 1839, pp. 179-85; Church Missionary Record, Vol. X, No, 8, August 1839, p. 184;

44 Although it is written in this letter that Mrs Lieder gave lesson to 100 people in the Harem, this number seems doubtful to us for several reasons. Firstly, it is necessary to suppose that there were enough bondwomen for gathering so many people in the Harem. Moreover, among those who attended the courses, the idea of their being educated by a missionary even in the fields such as sewing, embroidery or music would not have seemed reasonable. Moreover, regarding the educational approach of that period, which was dominated by mutual instruction, it is not probable that a single teacher would give lessons (applied lessons, moreover) to a group comprising 100 students. As it was not possible to examine the national resources, we left the issue for Egyptian historians and simply noted our objections.

45 Monday and Thursday (CMSA: Lieder to Jowett, December 20, 1838, CM/O48/25a).

46 It is meaningful that Mrs Lieder was only employed for embroidery instead of other subjects, as an attempt to decrease the effect of a missionary upon the daughters of Pashas in the Harem.

47 Mrs Lieder's work in the Harem had facilitated the getting closer of the two countries at the senior level, and by means of her efforts, gifts had been exchanged between Queen Victoria and the Harem of the Pasha Muhammed Ali (CMSA: Lieder to Coates, November 21, 1839, CM/O48/28; Heibetullah, the Secretary to Mrs Lieder, January 9, 1840, CM/O48/30b). Moreover, Mrs Lieder had sold some valuable things made at the GDS (tablecloths, etc.) in the Palace via this relationship and had made a considerable profit for the Egyptian Mission (CMSA: Lieder to Coates, October 12, 1840, CM/O48/42). 
Church Missionary Record, Vol. XII, No. 8, August 1841, pp. 179-180). On account of this custom, Lieder tried to get the children enrolled at the school as young as possible (CMSA: Lieder to the Sec.s of the CMS, January 25, 1839, CM/O45/75b; Lieder to the Sec.s of the CMS, 14 March 1845, CM/O48/121).

There was some doubt about the state and future existence of the Egyptian Mission in London, notwithstanding its progress of recent years.

\begin{tabular}{|c|c|c|c|c|c|c|}
\hline $\begin{array}{l}\text { Table } 2 \\
\text { The State of Society's } S \\
1839, p .185) .\end{array}$ & ols at th & End of & $(C M S A$ & $\operatorname{urch} M i$ & nary Rec & Vol. X, No. 8, August, \\
\hline Title of Schools & $\begin{array}{c}\text { Male } \\
\text { Teachers }\end{array}$ & $\begin{array}{l}\text { Female } \\
\text { Teachers }\end{array}$ & $\begin{array}{l}\text { Boarders } \\
\text { (Male) }\end{array}$ & $\begin{array}{l}\text { Male Day } \\
\text { School }\end{array}$ & $\begin{array}{c}\text { Female Day } \\
\text { School }\end{array}$ & $\begin{array}{l}\text { No. Total taught from } \\
\text { the beginning }\end{array}$ \\
\hline The Seminary & 3 & 0 & 11 & 14 & 0 & 121 \\
\hline The Boys' Day School & 3 & 0 & 0 & 84 & 0 & 761 \\
\hline The Girls' Day School & 1 & 3 & 0 & 0 & 137 & 253 \\
\hline Total & 7 & 3 & 11 & 98 & 137 & 1135 \\
\hline
\end{tabular}

After carrying out examinations at the English and American missionary stations in the Mediterranean, Lieder reported that he could not understand the reason for this doubt, and stated that the missionary work of all these Mediterranean stations was not different from that of the Egyptian Mission (CMSA: Lieder to Coates, January $24,1839, \mathrm{CM} / \mathrm{O} 48 / 26)$. The results of the exams that were taken in the presence of Mr Henry Tattam at the BDS and the GDS on January 25th, 1839, were an indication of this success (CMSA: Lieder to the Sec.s of the CMS, February 14, 1839, CM/ O48/27), and Lieder compared them to the results of other schools. ${ }^{45}$ In addition to listing the documents that verified his successes at the schools, he demonstrated that the expenditures for the continuation of the Mission had decreased, as well. ${ }^{46}$

Indeed, the feats achieved were remarkable, in particularly by the GDS. Moreover, Mrs Lieder had selected a class of ten of her most advanced pupils, which she instructed every day from 2 p.m. to 4 p.m. in English, sewing, and embroidery in addition to her attendance to the Harem (CMSA: Lieder to the Sec.s of the CMS, March 13, 1840, CM/O48/30a). It can be understood that Lieder's savings policy was abandoned after a short while, upon the new developments at the GDS. For example, initially the salary of school mistress, Um Suliman, was increased to ensure her continuing employment, ${ }^{47}$ and later new instruments were purchased for the school to incite the instruction of some of the most promising girls. These expenses all surpassed the allowed sum.

45 Henry Tattam's expressions that pointed out that he was impressed by the success of the schools had been inserted at the end of the letter (CMSA: Lieder to the Sec.s of the CMS, February 14, 1839, CM/O48/27).

46 For instance, the expenses of the year 1839 had not only been 241 dollars less than those of the year 1838, but the expenses for the first 6 months, 142 dollars, were also less than the allowed sum (CMSA: Lieder to the Sec.s of the CMS, March 13, 1840, CM/O48/30a).

47 The increase was from 15 to 20 dollars monthly (CMSA: Lieder to Coates, October 12, 1840, CM/O48/42). 
Nevertheless, Lieder continued to initiate new projects, such as selecting 20 girls from GDS whose parents he visited to ask if they would allow their daughters to receive instructions in Arithmetic and writing from a male teacher, Mr Ayoub. The reason for Lieder's initiative was to run a separate and higher class for training school mistresses at the GDS under the direction of a man. The higher class of the Girls' School was formed especially for this purpose, because the Society's funds evidently did not allow the opening of a female seminary (CMSA: Lieder to the Sec.s of the CMS, January 20, 1841, CM/O48/120; Church Missionary Record, Vol. XII, No. 8, August 1841, p. 180; Miss. Reg., August 1841, p. 379). Apart from these high class courses, the pupils also received religious instructions at an advanced level and other necessary subjects. Mrs Lieder also gave instructions in English and sewing, etc. In order to banish the fear of the Arab parents in respect to their daughters entirely, Lieder gave up one of his family's best rooms and turned it into a sophisticated school room, which meant that the school was intensively supervised by either Mr or Mrs Lieder from the beginning of the year 1841 (CMSA: Lieder to Coates, October 12, 1840, CM/O48/42; Lieder to the Sec.s of the CMS, January 20, 1841, CM/O48/120). On the other hand, Mrs Lieder's Harem courses had ceased in 1840 as a result of the political tensions caused by England's continuous intervention in Egypt's rule (CMSA: Lieder to Coates, October 12, 1840, CM/O48/42; Miss. Reg., August 1841, p. 376).

One of the negative developments for the Egyptian Mission, during this same time, was the deterioration of the relationship between Krusé and Lieder, the two representatives of CMS in Cairo. Reports from that date up until Krusé's resignation indicate hostility rather than solidarity between the two missionaries. ${ }^{48}$ Their dispute had perhaps not separated the schools, but it had divided their duties, which were integrated into two independent sections, with Lieder in charge of the educational department and Krusé of general business (CMSA: Lieder to the Sec.s of the CMS, July 4, 1845, CM/O48/61c).

The number of students at the schools continued to increase despite the differences between Krusé and Lieder, and reached its highest rate since opening, particularly at the GDS (CMSA: Lieder to the Sec.s of the CMS, January 20, 1846, CM/O48/62). The total number of students that attended the CMS schools had reached $1087^{49}$ between the years 1843 and 1846 (CMSA: Lieder to the Sec.s of the CMS, March 14, 1845, CM/O48/121).

The statistics of the schools' average attendance for the year 1846 were as follows (CMSA: Lieder to the Sec.s of the CMS, March 29, 1847, CM/O48/123):

\footnotetext{
48 "...there can be no further that communion or that sympathy and love which our work demands" (CMSA: Lieder to the Sec.s of the CMS, July 4, 1845, CM/O48/61; Lieder to the Sec.s of the CMS, March 19, 1845, CM/O48/60; Lieder to Mrs Krusé, June 9, 1845, CM/O48/61c).

49 This included the number of Coptic Institutions, which was not further explained in the study due to the paging requirements of the article.
} 


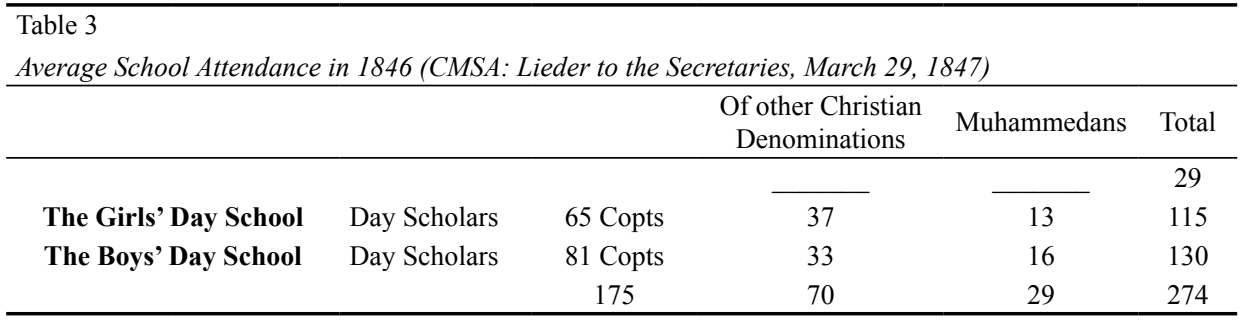

In contrast to the failure of the relationship between the missionaries, the GDS still continued its position of the Pearl of the Egyptian Mission (CMSA: Lieder to the Sec.s of the CMS, September 2, 1847, CM/O48/67). Despite this, Lieder could not remain non-reactive against the pressure of the Committee towards decreasing expenditures, and he had to introduce a firm savings policy, which included reductions on the teachers' salaries from 1848 (CMSA: Lieder to the Sec.s of the CMS, January 29, 1848, CM/O48/68). The amount allocated by the Society for the Egyptian Mission began to decrease year by year (CMSA: Lieder to the Sec.s of the CMS, January 27, 1849, CM/O48/124). 1848 was a difficult year for the GDS, perhaps not for financial reasons, but because of the cholera epidemic and government interventions. Despite these negative conditions, the GDS regained the full number of its former attendance shortly afterwards (CMSA: Lieder to the Sec.s of the CMS, January 27, 1849, CM/O48/124). However, the political condition of Egypt proved to be a trial for the Cairo Mission in 1849. It was first affected by the death of Ibrahim Pasha, and subsequently by concerns that the new Pasha might limit the progress the country had made during the reign of his predecessor (CMSA: Lieder to the Sec.s of the CMS, February 25, 1850, CM/O48/125). Nevertheless, Lieder's schools had to sustain an even more formidable rivalry with the Roman Catholic Church from the $1850 \mathrm{~s}$ onwards (CMSA: "Protestant Mission Schools in Egypt," CM/O48/126). However, the Patriarch continued to encourage the other schools, and as a result the Girls' School was still open in 1857 and was apparently the only institution of its kind in Egypt at that time (CMSA: CMS Record, Vol. XX, 1849, p. 155).

The mission work in Egypt continued for more than thirty years, chiefly by Lieder, who died in Cairo in 1865 (Stock, Vol. I, 1899, p. 351; Church Missionary Record, Vol. X (New Series), No. 9, September 1865, p. 264). One of the most important issues with Lieder's stability in the mission was his emotional connection to Egypt. He wrote about his feelings as follows: "Egypt has become to me a dear home, so that Ifelt myself a stranger in Europe even in my dear mother's house... May it please the Lord to prolong the days of my life and to bless my proceedings in this country..." (CMSA: Lieder to Coates, 27 August 1831, CM/O48/6; Lieder to Coates, October $29,1832, \mathrm{CM} / \mathrm{O} 48 / 12)$. Even though the signs of encouragement were not withheld, the Society did not feel warranted to reinforce or extend the Egyptian Mission 
and, with the deaths or retirement of its missionaries, it gradually came to an end. Although experienced and esteemed missionaries like Bishop Gobat urged that more missionaries should have been sent out to maintain the Protestant doctrine in Egypt, the CMS was unable to do more for Egypt. Even though Lieder remained at his post for many years and exercised a wholesome influence over the Coptic Patriarch and Bishops until his death from cholera in 1865 , the mission retained only a lingering existence and was closed three years before Lieder's passing..$^{50}$ Lieder died (CMSA: The Church Missionary Atlas, p. 65 in Hp 26) at the time that marked the decline of British missionary educational activities and the accession of the Francophile Ismail Pasha (1863 to 1879) to the Egyptian throne (Dicey, 1902, pp. 25-28). Therefore, the results of the mission were small and the enterprise had failed as a whole, however, hundreds of youths, particularly girls, had been educated properly by it. The curricula of the Society's schools showed that the missionaries aimed not only to instruct the pupils in the Christian religion by enabling them to read the Bible and by making them learn a certain amount of the text by heart, but that they also aimed for a much higher standard of developing the children's power of mind, to widen their outlook on life and to help them to form ideas.

\section{Conclusion}

During the nineteenth century, the commercial value and political importance of the Suez Canal and the overland route to India placed Egypt at the centre of the British Empire's interest. Even though the CMS regarded itself as 'anti to imperialist' and independent from the Empire's interests, the missionaries were identified by natives as conquerors and colonizers. In fact, a number of English traders subscribed to the missionary Society's funds and made suggestions of how the missionaries could further British commercial interests in the Mediterranean at the same time. It is interesting to note that one to third of the members of the first Committee of the CMS were merchants, bankers and brokers. However, political rather than economic factors were most relevant to the success of the British missions in Egypt.

In order to survive, mission schools had to be supported as a socially required service either by the Government or by parents. They needed equipment, buildings, and personnel. Muhammed Ali Pasha's economic support and security aid was not sufficient to ensure the Society's educational success in Egypt, because the missionaries failed to arouse a sufficiently strong and consistent sympathy for education in the communities that they had attempted to penetrate. Parental demands for useful education were often discouraged by ecclesiastical teachers, who feared that proselytization would occur.

50 Although Sislian states 1865 (death of Lieder) as the year of the first Egyptian Mission's closure, the correct date must be 1863 (1967, p. 188). 
Finally, to summarize what has been said above, according to the missionaries' experience, there were three different ways for establishing a permanent and stable mission in Cairo as well as in the Mediterranean: First, by spreading tracts and books with the assistance of the Malta press; second, by establishing schools for youths; and third, by preaching the Gospel, both publicly and from house to house. However, they did not manage to achieve a particular success in either of these ways in Egypt during this period.

The success of the mission schools is difficult to assess. In terms of their main purpose, conversion, they can hardly be said to have made a serious impact on Egypt. The Society's failure cannot be understood without explaining the general attitude towards education during the reigns of Abbas I (1849-54) and Said Pasha (1854-63), who were the predecessors of Muhammed Ali and whose rule constituted a considerable part of the period during which the CMS' first Egyptian Mission was active, particularly in relation to the missionary schools. For example, a considerable number of primary and preparatory schools as well as language and cavalry schools were abolished during the reign of Abbas I Pasha. It can be understood that Said Pasha openly displayed an adverse attitude against the education and enlightenment of the public. Said's following expression demonstrates his attitude towards this issue: "Why open the eyes of people, they will only be more difficult to rule" (Sislian, 1967, p. 216). Indeed, most of the institutions that had been opened under Muhammed Ali Pasha's reign had gradually disappeared. However, from 1863 to 1879 , when the pro-European Khedive Ismail came to power, education once more began to move forward in Egypt.

Another reason for the general lack of the mission school's success was the poverty of the pupils that came to them. The first Egyptian Mission's failure to reach its objectives may be related to the fact that the CMS put the entire burden on two missionaries' shoulders, along with a gradually decreasing budget for Cairo, where dozens of other missionaries were attempting to strengthen their position by making big investments. Although Lieder had created many opportunities, directly or indirectly, by means of his skills as physician that allowed him to exceed the competition between the different missions, his efforts did not appear very successful when the attendance rates of the schools were examined. However, even after the departure of the missionaries, the Western model for education and the teaching of English and European technological and social ideas would become part of later Egyptian nationalism.

The real success, therefore, is reflected in the educational achievements of the missionaries. In this respect, the extent to which mission schools dominated the educational systems of territories that were about to become independent has often been mentioned. The mission schools' freedom to proseltyse had been reduced by law in Cairo. But the number and quality of these schools made the people dependent on them. The Society's schools were regarded with suspicion for one main reason, 


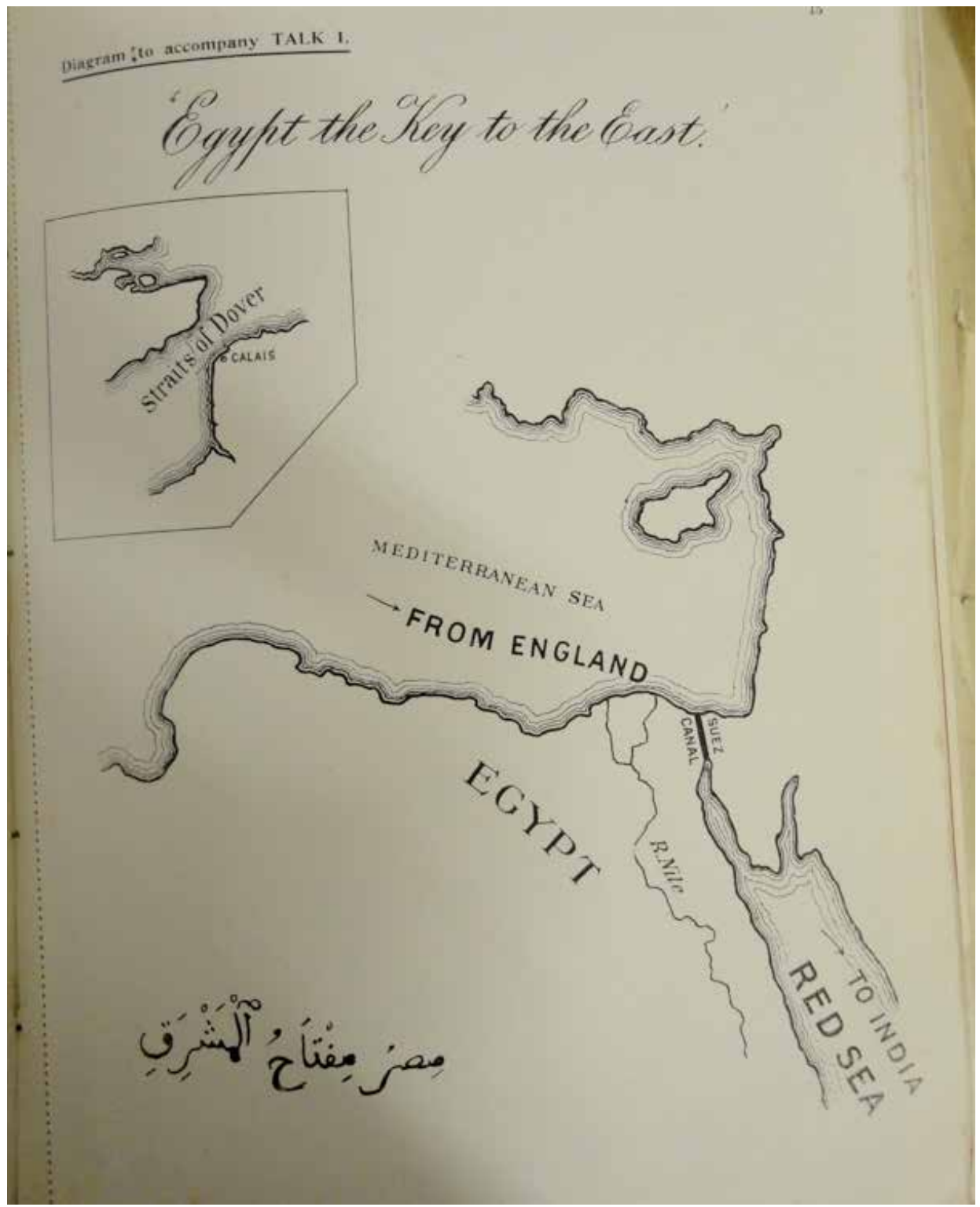

(Source: no a., Talks on Egypt, London: CMS Young People's Union, no d.)

namely, because they threatened indigenous institutions. The introduction of the English language and Christianity by mission schools represented cultural challenges to indigenous traditions.

The missionaries' policy was to convert people to Christianity, and the school was one of their agencies for conversion. But then, what caused the attendance of Muslim children at missionary schools that had been opened in cities at the heart of the Muhammedan world, such as Cairo? This question may be explained by the lack 
of scholarisation in the East. Missionaries successfully made use of that gap and won the approval of families that wished their children to be educated. Second, it can be understood that the missionary schools were preferred by children whose parents had died due to plague or another epidemics and by families that could not support their children due to poverty. However, the successes achieved by Mrs Lieder's school at that time, which included the fact that some Muslim parents sent their children to the school for educational purposes only as well as the fact that missionaries had even been allowed to enter the Harem, may not be denied. Nevertheless, in general terms, the attendance of Muslim students did not reach a remarkable level in the CMS schools during the period between 1825 and 1862, as this was not the Society's principle target and the Cairo mission was not supported to an extent that was comparable to the other societies.

\section{References}

Başbakanlık Osmanlı Arşivi (BOA) [Ottoman Archives], Kağıthane District, Istanbul, Turkey

Maarif Nezareti Mekatib-i Gayrımüslime and Ecnebiye Müfettişliği [Inspectorate of the Supervisory Ministry of Education for non-Muslim and Foreign Schools]. 6/85; 7/17; 8/39; 9/19.

Şura-yı Devlet Maarif [Consultation Polity for the Ministry of Education]. 208/42; 208/60;212/61; $213 / 1 ; 221 / 4 ; 221 / 7 ; 224 / 1$.

Church Missionary Society Archives (CMS Archives). Birmingham University, Birmingham, England.

Retrieved from http:/www.cms-uk.org/Resources/LibraryArchives/Archives/TabId/194/ArtMID/3826/ ArticleID/607/In-Birmingham.aspx

Church Mission Society Archive. (1840, January 18), CM/O48/30b; (n.d), CM/O51/14; (n.d), CM/ O51/21; (n.d.), CM/O51/22; (n.d.), CM/O51/25; (n.d.), CM/O73/42.

Church Missionary Atlas: 1857-1859. (Hp 26).

Church Missionary Gleaner. (1864), Vol. 14; (1874, May), Vol. 1.

Church Missionary Intelligence (1851, September). Vol. 2, No. 9

Church Missionary Monthly Paper (1829 August). Hp 35.

Church Missionary Quarterly Paper (1882, March). No. 269, (Hp 35).

Church Missionary Record. (1830, January), Vol. 1; (1831, April), Vol. 2, No. 4; (1832, May), Vol. 3, No. 5; (1832, December), Vol. 3, No. 12; (1834, May), Vol. 5, No. 5; (1834, July), Vol. 5, No. 7; (1835); (1836, January), Vol. 7, No. 1; (1838, March), Vol. 9, No. 3; (1839, August), Vol. 10, No. 8; (1840, May), Vol. 11, No. 5; (1841, August), Vol. 12, No. 8; (1843, April), Vol. 14, No. 4; (1845, May), Vol. 16, No. 5; (1847, May), Vol. 18, No. 5; (1848, May), Vol. 19, No. 5; (1849, July), Vol. 20, No. 7; (1850, May), Vol. 21, No. 5; (1865, September), [New Series] Vol. 10, No. 9.

Church Missionary Society Records. (1832), Vol. 4; (1836), Vol. 7; (1839), Vol. 10; (1840), Vol. 11; (1848), Vol. 19; (1849), Vol. 20.

Consideration on Mr. Lieder's practising medicine in Egypt for money (1831, July 2). CM/O39/138.

Dr. Richardson's Communications upon Egypt and Syria (1819, January 1). CME/3/38.

Fares Eshediak's Remarks concerning the children in the school at Cairo of the year 1832. CM/O73/61. 
Gobat to Kugler (1828, April 17). CM/O45/2.

Heibetullah the Secretary to Mrs. Lieder (1840, January 9). CM/O48/30b.

Hinde to Jowett (1826, March 4). CM/O8/10.

Isenberg to Coates (1834, April 8). CM/O73/67.

Isenberg to Schlienz (1834, July 1). CM/O73/71.

Journal of Mr. Krusé (1829, April 18). CM/O45/165.

Knoth to Coates (1836, June 20). CM/O8/31.

Krusé, Leider, \& Müller to Jowett (1828, February 4). CM/O73/12.

Krusé, Müller, Lieder, \& Kluge to Jowett (n.d.). CM/O73/23.

Krusé's Observations Relative to the Egyptian Mission (1832, September 13). CM/O45/27.

Krusé to Brenner (1830, October 30). CM/O48/53.

Krusé to Coates. (1831, August 17), CM/O45/21; (1833, October 30), CM/O73/63; (1833, November 20), CM/O45/31; (1834, January 15), CM/O45/33; (1834, January 15), CM/O45/32; (1836, June 17), CM/O45/48; (1836, June 30), CM/O45/176; (1838, January 24), CM/O45/61; (1838, March 21), CM/O45/63; (1838, April 30), CM/O45/47; (1839, January 22), CM/O45/71; (1840, September 10), CM/O45/89; (1841, November 10), CM/O45/77; (1842, March 18), CM/ O45/109; (1842, July 14), CM/O45/113.

Krusé to Jowett. (1828, February 4), CM/O73/12; (1835, August 25), CM/O73/77; (1837, October 4), CM/O45/58; (1837, November 25), CM/O45/59; (1839, December 20), CM/O45/82.

Krusé to Schlienz. (1828, July 12), CM/O73/24; (1829, August 12), CM/O73/24; (1828, October 31), CM/O73/26; (1829, June 20), CM/O73/30; (1838, April 12), CM/O73/21.

Krusé to the Secretaries to the CMS (1839). CM/O45/76.

Lieder to Coates. (1826, August 21), CM/O48/1; (1831, August 27), CM/O48/6; (1831, December 9), CM/O48/9; (1832, January 10), CM/O48/10; (1832, October 29), CM/O48/12; (1836, April 26), CM/O48/13; (1839, January 24), CM/O48/26; (1839, November 21), CM/O48/28; (1840, June 17), CM/O48/40; (1840, October 12), CM/O48/42; (1840, October 31), CM/O48/43; (1843, January 8), CM/O48/53.

Lieder to Jowett. (1827, January 17), CM/O73/5; (1831, September 9), CM/O48/7; (1838, December 20), CM/O48/25a.

Lieder to Lieder (1839, January 21). CM/O48/25b.

Lieder to Mrs. Krusé (1845, June 9). CM/O48/61c.

Lieder to Schlienz. (1828, June 20), CM/O73/24; (1829, January 16), CM/O73/29; (1829, February 21), CM/O73/29; (1836, January 25), CM/O73/80.

Lieder to the Secretaries. (1838, March 13), CM/O48/23; (1839, January 25), CM/O45/75a; (1839, January 25), CM/O45/75b; (1839, February 14), CM/O48/27; (1840, March 13), CM/O48/30a; (1840, March 17), CM/O48/119; (1841, January 20), CM/O48/120; (1841, January 28), CM/ O48/47; (1841, April 7), CM/O48/119; (1841, October 2), CM/O48/50; (1842, December 26), CM/O48/52; (1843, February 18), CM/O48/54; (1844, January 20), CM/O48/58; (1845, March 14), CM/O48/121; (1845, March 19), CM/O48/60; (1845, July 4) CM/O48/61c; (1846, January 20), CM/O48/62; (1846, May 20), CM/O48/122; (1846, August 3), CM/O48/65; (1847, March 29), CM/O48/123; (1847, September 2), CM/O48/67; (1848, January 29), CM/O48/68; (1848, January 29), CM/O48/68C; (1848, February 15), CM/O48/69; (1848, May 20), CM/O48/72; (1849, January 27), CM/O48/124; (1850, February 4), CM/O48/82; (1850, February 25), CM/ O48/125; (1850, August 5), CM/O48/88; (1851, April 11), CM/O48/90. 
Lieder to Venn (1847, May 19). CM/O48/66.

Minutes of a discussion with the Coptic Patriarch and an Interview held at the Patriarchate Cairo December 30th, 1839 (1840, July 22). CM/O48/41.

Missionary Papers (1822). No. 25, Lady-Day, (Hp 35).

Missionary Papers (1828). No. 51, Michaelmas, (Hp 35).

Missionary Register (1827); (1829, May); (1829, July); (1829, September); (1830, January); (1831, April); (1832, May); (1832, April); (1834, May); (1834, July); (1835, July); 1836, January); 1838, April); (1839, August); (1841, August); (1842, June); (1843, July); (1844); (1845, May); (1847, July); (1848, June); (1849, May); (1849, July); (1850, July).

Müller \& Krusé to Brenner (1835, January 26). CM/O73/73.

Müller, Krusé \& Lieder to Brenner (1831, January 11). CM/O73/52.

Müller to Coates. (1832, July 30), CM/O73/59; (1833, October 15), CM/O73/79; (1834, March 31), CM/O51/28; (1834, December 30), CM/O73/73.

Müller to Schlienz. (1834, June 9), CM/O37/55a; (1834, December 1), CM/O73/74.

Nazly \& Zeineb Hanum to the CMS (1838, December 30). CM/O48/25c.

Proceedings of the CMS for Africa and the East. (1815-1816); (1828); (1829); (1830); (1845); (1852); (1922-1923).

Protestant Mission Schools in Egypt (n.d.) CM/O48/126.

Report on the Past and Future of the Mediterranean Mission (1875). CM/O8/101.

The Star in the East and Friend of Youth (1834, August 29). CM/O6/15.

\section{Books and Articles}

Aksu, A. (2008a). Buzdağının ötesi: Amerikan board'un kuruluşunda (1810-1825) ve ilk faaliyetlerinde İngiliz misyonerlerin katk1lar1 [Beyond the iceberg: Contributions of British missionaries in the foundation of the American Board (1810-1825) and their first activities]. Kutadgubilig, 13, 293-316.

Aksu, A. (2008b). İngiltere-Amerika-Osmanlı hattında Lancaster öğretim sistemi [The Lancaster education system in the line of England, America, and the Ottomans]. Değerler Eğitimi Dergisi, 16, 29-67.

Altundağ, Ş. (1988). Kavalalı Mehmet Ali Paşa isyanı ve Misır meselesi: 1831-1841 [The rebellion of Mohamed Ali Pasha and the matter of Egypt]. Ankara, Turkey: Türk Tarihi Kurumu.

Arığ, A. S. (1999). Atatürk döneminde yabancı okulları (1923-1938) [Schools of foreigners in the time of Ataturk (1923-1938)]. Ankara, Turkey: Türk Tarihi Kurumu.

Aydın, M. (1996). Misyonerlik faaliyetleri ve Türkiye [Missionary activities and Turkey]. In Türkiye'de misyonerlik faaliyetleri (pp. 7-20). Ankara, Turkey: Türkiye Diyanet Vakfı Yayınlar.

Aykıt, D. A. (2008). Misyon ve Inciller: Misyonerliğin tarihsel kökenleri [Mission and the Gospels: The historical roots of the missionary]. İstanbul, Turkey: Kesit Yayınları.

Bartle, G. F. (1994). The role of the British and Foreign School Society in elementary education in India and the East Indies 1813-1875. History of Education, 23(1), 17-33. http://dx.doi.org/10.1 080/0046760X.2015.1076066

Buzpınar, Ş. T. (2003). Suriye ve Filistin'de Avrupa nüfuz mücadelesinde yeni bir unsur: İngiliz misyonerleri (19. Yüzyıl) [A new feature influencing the European struggle in Syria and Palestine: British missionaries (19th century)]. İslam Araştırmaları Dergisi, 10, 107-120. 
Church Missionary Society. (1910). The Palestine mission. London, England: W. Glowes \& Sons.

Coldwell, R. A. (n.d.). A Century of endeavour: The history of the Church Missionary Society in the lands of the Eastern Mediterranean during the nineteenth century (Unpublished manuscript).

Cragg, K. (2000). Being made disciples: The Middle East. In K. Ward \& B. Stanley (Eds.), The Church Missionary Society and world Christianity, 1799-1999 (pp. 120-143). Cambridge, England: Eerdmans Publishing Co.

Dallas, G. (2001). 1815: The roads to Waterloo. London, England: Pimlico.

Dalyan, M. G. (2012). 19. Yüzyılda Amerikalı misyonerlerin Hakkari günlüğü (1830-1870) [The Hakkari diary of American missionaries in the 19th century (1830-1870)]. İstanbul, Turkey: Öncü Kitap.

Danacioğlu, E. (1993). Osmanlı Anadolu'sunda Anglo-Sakson misyoner faaliyetleri [Anglo-Saxon missionary activities in Ottoman Anatolia]. (Doctoral dissertation, Dokuz Eylül University, İzmir, Turkey). Retrieved from https://tez.yok.gov.tr/UlusalTezMerkezi/

Davison, R. H. (1987, August). Osmanlı Türkiye'sinde Batılı eğitim [Western education in Ottoman Turkey] (M. Seyitdanlığlu, Trans.) Belleten, 51(200), 1031-1044.

Deringil, S. (2002). İktidarın sembolleri ve ideoloji. II. Abdülhamid dönemi (1876-1909) [Symbols and ideology of power: The period of Abdulhamid II (1876-1909)] (G. Çağalı Güven, Trans.). İstanbul, Turkey: Yapı Kredi Yayınları.

Dicey, E. (1902). The story of the Khedivate. London, England: Rivingtons.

Dinçer, N. (n.d.). Yabancı özel okullar (Osmanlı İmparatorluğu'nun kültür yoluyla parçalanması) [Foreign special schools (Cultural fragmentation of the Ottoman Empire]. İstanbul, Turkey: ERTU Matbaas1.

Erdoğan, D. İ. (2008). Amerikan misyonerlerinin faaliyetleri ve Van Ermeni İsyanları (1896) [American missionaries' activities and the Van Armenian revolt (1896)]. İstanbul, Turkey: IQ Yayınları.

Fortna, B. C. (2005). Mekteb-i hümayun. Osmanlı İmparatorluğu'nun son döneminde İslam, devlet ve egitim [Imperial classroom: Islam, the state, and education in the late Ottoman Empire] (P. Siral, Trans.). İstanbul, Turkey: İletişim Yayınları.

Gollock, M. C. (1906). River, sand, and sun being sketches of the CMS Egypt Mission. London, England: Church Missionary House.

Gündüz, Ş. (2004). Misyonerlerin çalışma yöntemleri [The work method of missionaries]. In Ö. F. Harman (Ed.), Türkiye'de misyonerlik faaliyetleri. tartışmalı ilmi toplantı (pp. 349-376). İstanbul, Turkey: Ensar Neşriyat.

Gündüz, Ş., \& Aydın, M. (2002). Misyonerlik: Hiristiyan misyonerler, yöntemleri ve Türkiye'ye yönelik faaliyetleri [Missionary: The methods and actions of Christian missionaries related to Turkey]. İstanbul, Turkey: Kaknüs Yayınları.

Haboubi, F. (2010). Anglo-Sakson Protestan teşkilatlarının Türkiye'deki faaliyetleri [Anglo-Saxon Protestant organizational activities in Turkey]. (Doctoral dissertation, Marmara University, İstanbul, Turkey). Retrieved from https://tez.yok.gov.tr/UlusalTezMerkezi/

Halidi, M., \& Ferruh, Ö. (1968). İslam ülkelerinde misyonerlik ve emperyalizm [Missionaries and imperialism in Islamic countries] (O. Şekerci, Trans). İstanbul, Turkey: Kalem Kitabevi.

Haydaroğlu, İ. P. (1993). Osmanlı Imparatorluğu'nda yabancı okullar [Foreign schools in the Ottoman Empire]. Ankara, Turkey: Ocak Yayınları.

Hewitt, G. (1971). The problems of success. A history of the Church Missionary Society 1910-1942 (Vol. 1). London, England: SCM Press Ltd.

Heyworth-Dunne, J. (1939). An introduction to the History of education in modern Egypt. London, England: Luzac \& Co. 
Holmes, B. (1967). British Imperial policy and the mission schools. In B. Holmes (Ed.), Educational policy and the Mission Schools: Case studies from the British Empire (pp. 5-44). London, England: Routledge \& Kegan Paul.

Joint Committee on the Survey of Christian Literature for Moslems. (1923). Christian literature in Moslem lands: A study of the activities of the Moslem and Christian press in all Mohammedan countries. New York, NY: George H. Doran Company.

Jowett, W. (1822). Christian researches in the Mediterranean from MDCCCXV to MDCCCXX: In furtherance of the objects of the Church Missionary Society. London, England: Seeley, Hatchard, \& Son.

Karas, S. F. (1986). The Copts since the Arab invasion: Strangers in their land. Jersey City, NJ: American, Canadian, Australian C. Coptic Associations.

Keskinkılıç, E. (2008). Biblelands arşivi ve Osmanlı topraklarında İngiliz misyoner Evangelist faaliyetleri [Actions of the English Evangelist missionaries in the Bible lands archive and Ottoman lands]. Akademik Araştırmalar Dergisi, 37(10), 102-120.

Kırşehirlioğlu, E. (1963). Türkiye'de misyoner faaliyetleri [Missionary activities in Turkey]. İstanbul, Turkey: Bedir Yayınları.

Kocabaşoğlu, U. (1988). Osmanlı İmparatorluğu'nda XIX. yüzyılda Amerikan matbaaları ve yayımc1lı̆̆ [American printing and publishing in the Ottoman Empire in the 19th century]. In A. Aybay \& R. Aybay (Eds.), Murat Sarıca Armağanı (pp. 267-286). İstanbul, Turkey: Aybay Yayınları.

Kocabaşoğlu, U. (1989). Anadolu'daki Amerika [America in Anatolia]. Ankara, Turkey: İmge Yayınları.

Latourette, K. S. (1946). A history of the expansion of Christianity (Vol. 6). London, England: Eyre \& Spottiswoode.

McGregor, A. J. (2006). A military history of modern Egypt: From the Ottoman conquest to the Ramadan War. Westport, CT: Praeger Security International.

Morrison, S. A. (1936). The way of partnership with the CMS in Egypt and Palestine. London, England: Church Missionary Society.

Mutlu, Ş. (2005). Osmanlı Devleti'nde Misyoner Okulları [Missionary schools in the Ottoman State]. İstanbul, Turkey: Gökkubbe Yayınları.

Nurdoğan, A. M. (2009). Lord shall be taught to Egypt: The girls' boarding school in Babelluk (1892-1923). Education, 129(4), 770-787.

Oymak, İ. (2012). Metot ve çalışma alanları açısından Türkiye'de misyonerlik faaliyetleri [Missionary activities in Turkey in terms of method and areas of operation]. İstanbul, Turkey: Ankara Okulu Yayınları.

Özdalga, E. (2005). Christian community schools during the Ottoman Reform Period: Late Ottoman society. In E. Özdalga (Ed.), Late Ottoman society: The intellectual legacy (pp. 254273). London, England: Routledge Curzon.

Polvan, N. (1952). Türkiye'de yabancı ögretim [Foreign education in Turkey]. Ankara, Turkey: Millî Eğitim Bakanlığı.

Quataert, D. (2004). 19. yüzyıla genel bakış: Islahatlar Devri 1812-1914 [Ageneral look at the 19th century: The reform period of 1812-1914]. In H. İnalckk \& D. Quataert (Eds.), Osmanl İmparatorluğu'nun ekonomik ve sosyal tarihi (Vol. 2, pp. 885-1052). İstanbul, Turkey: Eren Yayınları.

Register of Missionaries (Clerical, Lay \& Females) and Native Clergy from 1804 to 1904. (n.d.). P. I. CMS: Printed for Private Circulation.

Semple, R. A. (2003). Missionary women: Gender, professionalism and the Victorian idea of Christian mission. Woodbridge, England: Boydell. 
Sevinç, N. (2007). Osmanlı'dan günümüze misyoner faaliyetleri: Okullar, kiliseler ve yardım kuruluşları [Missionary activities from the Ottoman Empire to today: Schools, churches, and charities]. İstanbul, Turkey: Bilgeoğuz Yayınları.

Sislian, J. (1967). Missionary work in Egypt during the nineteenth century. In B. Holmes (Ed.), Educational policy and the mission schools: Case studies from the British Empire (pp. 175-240). London, England: Routledge \& Kegan Paul.

Somel, S. A. (2010). Osmanlı'da Eğitimin Modernleşmesi (1839-1908): İslamlaşma, Otokrasi ve Disiplin [Modernization of education in the Ottoman Empire (1839-1908): Islamization, autocracy, and discipline]. İstanbul, Turkey: İletişim Yayınları.

Stock, E. (1899/1916). The history of the Church Missionary Society. Its environment, its men, and its work (Vol. 1-4). London, England: Church Missionary Society.

Sundkler, B., \& Steed, C. (Eds.). (2000). The Church Missionary Society and World Christianity, 1799-1999. Cambridge, England: Cambridge University Press

Tozlu, N. (1991). Kültür ve eğitim tarihimizde yabancı okullar [Foreign schools in our history of culture and education]. Ankara, Turkey: Akçağ Yayınları.

Turan, S. (2011). Misyoloji. Hiristiyan Misyon Bilimi [Missiology. The science of the Christian mission]. Ankara, Turkey: Sarkaç Yayınları.

Tümer, G., \& Küçük, A. (1993). Dinler tarihi [The history of religions]. Ankara, Turkey: Ocak Yayınları.

Vahapoğlu, H. (1997). Osmanlı'dan günümüze azınlık ve yabancı okulları [Minority and foreign schools from the Ottoman Empire to today]. Ankara, Turkey: Millî Eğitim Bakanlığı.

Weigall, A. E. P. B. (1915). A history of events in Egypt from 1798 to 1914. Edinburgh, Scotland and London, England: W. Blackwood.

Wilson, K. (2002). The island race: Englishness, empire, and gender in the eighteenth century. London, England \& New York, NY: Routledge.

Young, G. (1927). Egypt. London, England: Benn. 